\title{
Promoting Social Sustainability of Urban Neighbourhoods The Case of Bethnal Green, London
}

Author 1 (Corresponding Author):

M. Reza Shirazi, School of the Built Environment, Oxford Brookes University, Oxford, UK Email:shirazi@brookes.ac.uk

Postal Address: Oxford Brookes University, Headington Campus, Gipsy Lane (AB120), Oxford OX3 OBP UK

Author 2:

Ramin Keivani, School of the Built Environment, Oxford Brookes University, Oxford, UK Email: rkeivai@brookes.ac.uk

Author 3:

Sue Brownill, School of the Built Environment, Oxford Brookes University, Oxford, UK Email: sbrownill@,brookes.ac.uk

Author 4:

Georgia Butina Watson, School of the Built Environment, Oxford Brookes University, Oxford, $U K$

Email: gbutina@brookes.ac.uk

Keywords: urban neighbourhoods, social sustainability, neighbourhood enhancement index, social sustainability evaluation

\section{Abstract}

Growing significance of neighbourhoods in different areas of urban planning, along with the increasing attention to the social dimension of sustainable communities and societies, emphasizes the need for conceptualizing socially sustainable neighbourhoods. This article first critically reflects on the concept of socially sustainable neighbourhoods in two areas of definition and operationalization. It then proposes a tripartite framework for measuring social sustainability of urban neighbourhoods which combines three elements of neighbourhood, neighbouring, and neighbours. This framework is tested, examined, and discussed in the case of Bethnal Green, London. The findings are integrated into a Social Sustainability Enhancement Index which encompasses practical recommendations to promote social sustainability of Bethnal Green. The article concludes with highlighting research and policy implications of the proposed framework, and suggests some methodological improvements for the future research. 


\section{Introduction}

The three-dimensional tripartite structure of sustainable development as the meeting point of three pillars of ecology, economy, and society (equity) has been subject to criticism. Some scholars accept the triad structure but argue for a balanced emphasis on the three integral components (Dale and Newman, 2010; Winston and Pareja Eastaway, 2008). Others from a revisionary standpoint either add one or more pillars to the classic triad of sustainable development, such as culture, liveability, governance, politics, and ethical values, and propose four-pillar or multi-pillar structures, or introduce alternative schemes and frameworks (Leal Filho et al., 2016; Soini and Birkeland, 2014; Psarikidou and Szerszynski, 2012). Despite these critiques, the social dimension of sustainable development remains a valid component of urban sustainability (Shirazi and Keivani, 2017; Peterson, 2016; Opp, 2016).

In line with the growing significance of urban neighbourhoods in different areas of urban planning and design (Galster, 2019; Brownill and Bradley, 2017; Bradley, 2017; Pagano, 2015; Davoudi and Madanipour, 2015), social sustainability of urban neighbourhoods attracts attention of researchers and policy makers for different reasons. Firstly, some scholars introduce neighbourhood as a practical scale for urban administration and urban governance and a proper urban territory to tackle different social problems such as poverty, social exclusion, gentrification, etc. (Pagano, 2015; Durose and Lowndes, 2010; Lowndes and Sullivan, 2008; Lawless, 2006; Alcock, 2004; Kearns and Parkinson, 2001; Chatterton and Bradley, 2001). Secondly, approaching neighbourhood as a practical scale for intervention has convinced local or national authorities to propose a large number of neighbourhood-oriented initiatives and programmes which have direct social impacts on the urban life of the inhabitants, such as renewal projects and regeneration programmes (Bailey and Pill, 2011; Lawless et al., 2010; McDonald et al., 2009; Atkinson, Rowland and Kintrea, 2002; Dobbs and Moore, 2002; Sullivan, 2001; Atkinson, Rowland and Kintrea, 2000; Kleinman, 1999). Thirdly, influenced by the concept of 'sustainable communities' which has developed as a prototype for sustainable development (Roseland, 2012; Hempel, 1999), developers and policy makers have introduced 'sustainable neighbourhoods' as model sustainable developments that create socially sustainable environments (Lees, 2014; Winston, 2014; Lafferty, 2014; Cochrane, 2012; Brownill and Carpenter, 2009; Roseland, 2012; Mazmanian and Kraft, 1999). Fourthly, neighbourhoods have been understood as a site for achieving vibrant, cohesive societies which deliver high qualities of life (Walton et al., 2008a; Kennett and Forrest, 2006; Christensen and O'Brien, 2003; Stafford et al., 2003; Forrest and Kearns, 2001). Finally, it is a long-standing scholastic question to know which type of urban neighbourhoods, in terms of socio-spatial 
characteristics, are socially more sustainable, and to which directions urban neighbourhoods should envision their future (re)development schemes (Jenks and Jones, 2010; Raman, 2010; Bramley and Power, 2009; Jabareen, 2006; Parkes et al., 2002; Jenks et al., 1996).

Debates on socially sustainable neighbourhoods face a two-fold challenge should advance in three directions. On the one hand, although a large body of knowledge has been recently produced on this topic so that "urban social sustainability discourse has moved from an 'undertheorised' status to an 'insufficiently theorised' status", more theoretical research should be conducted to consolidate the discourse and advance its theory (Shirazi and Keivani; 2019a, p. 216). On the other hand, there is a need to develop working frameworks (Yoo and Lee, 2016; Landorf, 2011), particularly for the neighbourhood scale, that can enable assessment of basic qualities of a socially sustainable neighbourhood in a given urban setting. As will be noted later, scholars have suggested working definitions and evaluation frameworks for measuring social sustainability of urban neighbourhoods and successfully applied to various case studies. However, there is a need to build on these efforts and develop frameworks that offer a more comprehensive structure of analysis that link qualitative and quantitative aspects of social sustainability. Moreover, evaluation frameworks can be utilised by policy-makers, planners, and designers as an analytical and explanatory tool to identify existing social sustainability challenges of a given context (here, urban neighbourhoods) and guide them to develop practical recommendations to address them. These challenges are in line with the normative nature of planning discipline and sustainability discourse. As an inherently normative enterprise, they are informed by normative values, ideas and ethics which occupy the very question of what should be done (Winkler and Duminy, 2016; Campbell, 2012), presuppose priority of some ethical judgements over others, and rests upon a search for a 'better' future (Healey, 2012). The question to be answered is, to what extent can social sustainability, in both theory and practice, depart from a primarily normative paradigm and gain a context-situated character.

The main objective of this article is to contribute to the existing body of knowledge about urban social sustainability and building on it to develop a framework for measuring social sustainability of urban neighbourhoods. Furthermore through its application to a case study to show how this framework can identify current challenges and provide us with reliable data to develop policy and practical recommendations to promote social sustainability. To achieve this, we first review recent debates on social sustainability and underline its theoretical and practical achievements and challenges. This paves the way for conceptualising social sustainability for urban neighbourhoods. Then, building on existing work about social sustainability of urban neighbourhoods, we propose a working definition and an evaluation framework for measuring 
social sustainability of urban neighbourhoods. This framework is tested, examined, and discussed in a pilot case study neighbourhood, Bethnal Green, London. The findings serve as a platform for making practical policy, planning, and design recommendations through which the social sustainability value of Bethnal Green could be improved. We conclude the article with highlighting research and policy implications of the proposed framework, and suggest some methodological improvements for future research.

\section{Social Sustainability in Theory and Practice}

It has been often argued that "there is a relatively limited literature that focuses specifically on social sustainability" (Dempsey et al., 2011), so that scholars call for a comprehensive study of this concept and further theoretical investigations (Opp, 2016; Colantonio and Dixon, 2011; Cuthill, 2010). Our review of the existing literature confirms the argument of Manzi et al (2010, p. 1) that "different people mean different things when they discuss social sustainability." In fact, the concept has been approached and defined from different standpoints and perspectives: an engine for fostering cultural development and diversity; a process for achieving a sustainable future; a practical tool for urban policy to improve quality of life; a tool for fair distribution of urban goods; a framework for supporting individual and collective well-being of the inhabitants; a platform for practicing equity and democracy for all the people; and capacity building for individuals and society to address ecological and spatial inequalities. This diversity of interpretations and approaches, as Davidson (2010) puts it, is not only inevitable but also desirable. It grants the concept of social sustainability a fluidity which makes it appropriate for reflecting on diverse aspects and complex nature of urban societies. This fluidity and flexibility presents social sustainability as 'a constructive dialogical arena': "It presents itself as a bridge language, a lingua franca, to establish, maintain, and promote dialogue and communication" (Shirazi and Keivani, 2019a, p. 217).

A number of scholars have successfully developed evaluation frameworks and a set of indicators to measure social sustainability of the built environment. A review of these operationalisation efforts guides us to four key observations. Firstly, social sustainability has been approached both as a substantive and relational criterion. Here while some studies intend to study social sustainability qualities in a given context (Lang, 2019; Hamiduddin and Adelfio, 2019; Landorf, 2019; Opp, 2016; Harris and Weiner, 1998; Bacon et al., 2012; Colantonio and Dixon, 2011; Chan and Lee, 2007; Chiu, 2003a), others investigate the relation of social sustainability indicators to other physical or non-physical dimensions of the built environment such as density, urban design, and planning (Netto et al., 2019; Shirazi and Keivani, 2019b; 
Karuppannan and Sivam, 2011; Jenks and Jones, 2010; Raman, 2010; Dave, 2010; Bramley et al., 2009; Bramley and Power, 2009; Burton, 2000a; Yiftachel and Hedgcock, 1993a). Secondly, social sustainability has a multiscalar character and hence is relevant to different territories from the regional (e.g. urban region) to the local (e.g. residential complex) scale (Shirazi and Keivani, 2017). Thirdly, operationalisation of social sustainability has been exercised as developing a number of indicators, the quantity (number) and nature (e.g. physical or non-physical) of which is determined by the goal (objective) and scale (territorial coverage) of the inquiry (Dempsey et al., 2011; Bramley et al., 2009; Boschmann and Kwan, 2008; Chiu, 2004). Fourthly, social sustainability indicators have shifted from primarily quantitative qualities to predominantly qualitative ones, and this reflects the substantial capacity of the social sustainability concept in addressing non-physical needs of a sustainable environment (Shirazi and Keivani, 2019a; Colantonio and Dixon, 2011).

These observations in both theory and practice of social sustainability provide us with helpful pointers to propose our working definition for socially sustainable neighbourhoods, and develop a working framework for measuring and assessing social sustainability of urban neighbourhoods in the following sections.

\section{Socially Sustainable Neighbourhoods, Definition and Indicators}

In one of our previous works a qualitative meta-analysis of 73 studies (for details see: Shirazi and Keivani, 2017) revealed two informative characteristics of social sustainability. Firstly, despite diversity and ambiguity of definition, social sustainability has been conceptualised around a number of key principles such as equity, democracy and social engagement, social inclusion and social mix, social interaction, sense of place, safety and security, and quality of the built environment and dwelling. Secondly, social sustainability embraces both non-physical aspects of the built environment - for example human interaction (Yiftachel and Hedgcock, 1993b), sense of community (McKenzie, 2004), social interaction (Dempsey, Nicola et al., 2011; Bramley and Power, 2009) — and physical aspects — for example access to urban services (McKenzie, 2004), urban infrastructure (Bacon et al., 2012), and internal and external housing conditions (Chiu, 2004). This indicates that a socially sustainable environment has a dialectical character: it is a locality where physical qualities and standards are positively perceived, highly valued, and interactively utilised by the inhabitants through sustaining and endurable social practices, and a place where substantial social qualities are sustained, highly valued, and vividly exercised within an urban setting of high physical quality. This provides us with a critical clue: qualitative and quantitative dimensions of social sustainability are interlinked and 
interconnected. To achieve an integrative structure, we suggest a conceptual framework that builds on studies in which social sustainability of neighbourhoods has been defined and tested in different case studies (e.g. Dempsey, et al., 2012; Dempsey et al., 2011; Bramley et al., 2009) and intend to advance it through bringing together quantitative and qualitative qualities into a single framework that enables a more comprehensive understanding from the dynamics of social sustainability. To do so, and building on the key principles and abovementioned arguments extracted from the literature, we conceptualise socially sustainable neighbourhoods as localities where both physical and non-physical qualities are highly valued and interactively practiced by the inhabitants. This definition suggests a three-pillar structure: the space within which social sustainability is practiced and evaluated (neighbourhood), the practice of social qualities by the inhabitants (neighbouring), and the people who exercise these practices (neighbours). In this sense, social sustainability of neighbourhood is the interaction between the three pillars of 'neighbourhood', 'neighbouring', and 'neighbours'.

The 'neighbourhood' pillar investigates physical qualities of the neighbourhood space and thus is a matter of urban form. Drawing on a thematic analysis of a large number of studies on urban form (42 in total) and building on the relevant studies at the neighbourhood scale (e.g. NedovicBudic et al., 2016; Karuppannan and Sivam, 2011; Dempsey et al., 2010) we propose five indicators of density, mixed land use, urban pattern and street network, building typology, and quality of centre for measuring the 'neighbourhood' pillar of social sustainability (See Table $1)$.

Density quantifies the concentration of individuals (e.g. population density) or physical structures (e.g. building density) within a specific territorial area, using a set of conventional measures (Grosvenor and O’Neill, 2014). Although primarily a quantitative measure, density is associated with different social dimensions such as sense of attachment (Nasar and Julian, 1995), and social equity (Dave, 2010; Burton, 2000; Williams, et al., 1996). Mixed land use addresses the combination of different functions in a determined place and their proximity and diversity (Foord, 2010; Rodenburg and Nijkamp, 2004). It brings close together local services needed for neighbourhood residents and enhances access to basic urban amenities (Foord, 2010; Jabareen, 2006). Urban pattern investigates spatial arrangement and configuration of different urban elements including streets, blocks, and buildings (Dempsey et al., 2010) and describes connectivity, integration, and permeability of space (Hillier, 2002, 1996). Building typology studies diversity of buildings based on common formal characteristics (Scheer, 2010). Type (e.g. detached, semi-detached, terraced, etc.), height (e.g. low-rise, high-rise), age (e.g. pre-war, post-war, etc.), function (e.g. residential, office, educational, etc.), and style (e.g. Victorian) are 
common categories for typologizing buildings. Quality of the centre investigates spatial qualities of the neighbourhood's focal point in order to explore both spatial potentialities and physical shortcomings of the neighbourhood centre and its capacity in providing needed services. It covers a wide range of issues such as land use (e.g. vertical and horizontal land use of the building plots around the neighbourhood centre), spatial configuration (e.g. size and connectivity to the neighbourhood space), environmental qualities (e.g. cleanliness, green space), and infrastructure (e.g. sufficient urban facilities, furniture, play grounds).

The 'neighbouring' pillar of social sustainability triad investigates non-physical qualities of neighbourhood with social implications, such as social ties and relations, public engagement, sense of attachment, and feeling of security, to name but a few (Skjaeveland et al., 1996; Greider and Krannich, 1985). An analysis of 33 studies which investigate different modes of neighbouring suggest some pointers to identify the most relevant indicators. Firstly, the concept of 'neighbouring' has been theorised, discussed, and developed around some key factors such as equal accessibility; democracy, participation, and civic society; social inclusion and mix; social networking and interaction; livelihood and sense of place; safety and security; human well-being and quality of life. Moreover, the scale factor is a decisive criterion for selecting relevant indicators (Shirazi and Keivani, 2017): some social factors such as employment are more relevant to the city and region scale than the local. Based on the findings of the analysis and considering the objective and scale of our research we propose seven indicators for measuring 'neighbouring' pillar of social sustainability: access to facilities, social networking and interaction, safety and security, sense of attachment, participation, neighbourhood quality perception, and home quality perception (see Table 1).

Access to facilities addresses two issues: availability of key urban amenities needed at the neighbourhood level for the neighbourhood residents, and equal accessibility of these amenities to all the members of the community, including ethnic minorities, disabled, elderly, and children. In other words, accessibility implies a fair distribution of basic urban services across the neighbourhood space (Talen, 2003; Barton, 2000b). At the neighbourhood scale, accessibility of amenities should be evaluated on the basis of walkability of destination (Talen, 2003); some scholars have suggested minimum accessibility standards for local facilities with different density patterns (Tsou et al., 2005; Barton et al., 2010). Social interaction and networking addresses the interaction between two or more individuals, and covers a range of non-verbal or verbal interrelationships which may lead to strong social networks and better quality of life (Argyle, 2007). Social interaction contributes to stronger social networks and better quality of life (Kavanaugh et al. 2005). Despite the change in 
networking patters due to digital technology (Kraut et al. 2006; Brignall and Van Valey 2005), neighbourhood space still accommodates different types of socialising activities and social interaction (Shirazi, 2018). The feeling of safety and security is related to the external and internal threats; a safe neighbourhood is attractive for the people, particularly children and elderly, and encourages people to socialise in the public spaces (Brounen et al., 2012; Raco, 2007). Feeling of safety at the neighbourhood scale covers a range of issues such as traffic safety particularly for children and elderly (Dempsey, et al., 2012; Bennett et al., 2007), and feeling safe against different types of crime particularly at night and for more vulnerable residents (Foster et al., 2010; Carver et al., 2008).

Sense of attachment and belonging is about sense of place; identifying ourselves with the place and feeling attached to it (Relph, 1976). This attachment could be our engagement with the physical space and our identification with spatial qualities and environmental characteristics, or our connectivity with the community members based on shared values, common interests, and human ties (Rogers and Sukolratanametee, 2009). People who identify themselves with their 'place' and have a high sense of attachment are more likely to conserve it and stay for a long period there (Elkin et al., 1991; Comstock et al., 2010). Participation is related to the level of engagement of residents in dealing with neighbourhood problems, their active involvement in neighbourhood-related initiatives and NGOs, and is an indication of community vibrancy (Teernstra and Pinkster, 2016; Michels and De Graaf, 2010).

Neighbourhood participation is exercised through different types of activities such as local elections, charity activities, neighbourhood-related initiatives, protests and social mobilisation, and active membership in NGOs. Studies show that different factors affect the level of community participation, such as the age, gender, length of residency, education, and social networks (Weingaertner and Moberg, 2014; Dekker, 2007). Neighbourhood quality studies to what extent residents are satisfied with their immediate environment (Oktay et al., 2009; Walton et al., 2008b). It can cover residents' perception of a range of neighbourhood characteristics and qualities. For example, physical quality of the neighbourhood includes maintenance, architectural character, landscaping, cleanness, and quietness (Sirgy and Cornwell, 2002; Lee et al., 2016). Quality of neighbourhood is also about the feeling of residents regarding crowding, or perceived density which is subjective and differs from physical density that was introduced earlier as an indicator for measuring neighbourhood pillar (Dave, 2011). Studies show that higher neighbourhood quality is associated with neighbourhood satisfaction and feeling of safety and security (Lovejoy et al., 2010; Austin et al., 2002). Finally, home quality perception is an indication of the degree of congruence 
between the actual and the desirable home conditions and residents' perception of different aspects of home (Byun and Ha, 2016; Barreira et al., 2016). It is both about the residents' satisfaction with the quality of interior space, including size of rooms and spatial arrangement of rooms, and the quality of immediate exterior such as sense of privacy, noise, and green space. Studies show that low level of home satisfaction can have negative impacts on health, social relations, privacy, and education (Dave, 2011).

The 'neighbours' pillar (see Table 1). studies population profile of the neighbourhood inhabitants in order to gain an in-depth knowledge about the residents with regard to age/gender distribution, ethnicity mix, length of residency, household size, household type, house ownership, household income, employment status, accommodation type and characteristics, and education status. This is achieved through a major indicator of 'social mix' and shows the state of neighbourhood diversity according to socioeconomic status (Galster and Friedrichs, 2015). This indicator provides valuable insights from the people who use the neighbourhood space (neighbourhood pillar), and exercise social activities and generate social space (neighbouring pillar). In case several neighbourhoods are studied and a comparative analysis is required, some aspects of the 'neighbourhood pillar' such as level of deprivation could be investigated in more details, as it can explain how different aspects of deprivation correlate with other indicators of 'neighbourhood' and 'neighbouring'. Studies show that Existing national or local area deprivation studies could be a valuable source for the analysis, such as the Index of Multiple Deprivation (IMD) which is the official measure of relative deprivation for small areas in England (available here: https://www.gov.uk/government/statistics/english-indices-ofdeprivation-2015). As will be explained later, these data would help us to understand results derived from neighbouring and neighbourhood indicators.

\section{Methodology: A Framework for Measuring Social Sustainability of Neighbourhoods}

The proposed definition was developed into a framework for measuring social sustainability, and was tested in the case of Bethnal Green neighbourhood in London utilising a multimethod approach for addressing different aspects of the work. Different characteristics, some of which will be elaborated later, make Bethnal Green an appropriate case for testing the methodology: as part of East London it has a strong tradition of community urban life; it has been subject to different re-development programmes; it has experienced social change towards a diverse social profile in terms of ethnicity, religion, and economic status; and it has a diverse physical environment in terms of land use. Being aware of the conceptual debates on the nature and definition of neighbourhoods, and practical complexity of delineating neighbourhood 
boundaries (Brindley et al., 2018; Park and Rogers, 2015; Coulton et al., 2013; Jenks and Dempsey, 2007), to define neighbourhood area we first delineated a tentative border line informed by historical evolution, recent urban transformation, and spatial characteristics of the area such as main- infrastructure and major traffic arteries. Interviews with 15 neighbourhood residents in the later stages of the research who were asked to draw their perception from neighbourhood boundaries showed that the proposed borders to a great extent match their mental map regarding the neighbourhood area and limit.

We developed the proposed tripartite structure in to a 4-stage framework including data collection, data processing, analysis, and recommendation. For measuring and processing 'neighbourhood' pillar (based on five identified indicators) data were collected from available sources such as national census, local surveys, GIS maps, and Ordnance Survey Maps, completed by intensive fieldwork. This included building by building on-site observation for collecting data regarding their physical characteristics such as number of floors and land use, as well as the usage pattern of neighbourhood space, quality of green space, urban furniture, etc. Collected data were processed by ArcMap Software which enabled us to run different enquiries and produce informative illustrations and maps with valuable information regarding density, land use, and building typology. We used Depthmap Software for studying configurational properties of urban structure, measuring the relationship between urban components, and investigating the level of integration of the Bethnal Green neighbourhood at the local and global (city) scale (Hillier, 2002, 1996).

Since the 'neighbouring' pillar addresses different neighbouring activities exercised by the inhabitants, we referred directly to the neighbourhood inhabitants. We designed a questionnaire in which each indicator is developed into a set of questions in order to gain an in-depth knowledge regarding different aspects of each indicator (see Table 1). To gauge the eligibility of the questions and language used we piloted the questionnaire with a small number of community members (15 in total) and required amendment were made. We conducted a household survey across the neighbourhood. It is important to note that due to resource and time limitations logistically it was not possible for us to undertake a statistically representative random sample survey of the neighbourhood. As such we aimed to achieve an illustrative sample of 'neighbouring' indicators based on building typologies that cover different housing types and enable understanding social interaction under different spatial conditions and environmental conditions created by the different typologies (e.g., high rise apartment blocks, medium rise developments and terraced housing). Since neighbourhood blocks possess distinct spatial characters with different building typologies, this helped us identify 9 urban areas which 
included 4 estates and residential complexes, one central area with Victorian houses, and four peripheral areas with mixture of residential and non-residential land uses. Based on a spatially stratified non-representative systematic random sampling, we targeted distributing 250 questionnaires using drop and collect method as it results in a higher response rate (Allred and Ross-Davis, 2011; Clark and Finley, 2007). A second collection round was arranged in case respondents couldn't complete the questionnaire in the first collection round. In total, 216 questionnaires were distributed based on availability and interest of the households, 100 were collected. This provides us with sufficient critical mass for undertaking the noted relevant statistical analyses for our purpose (Somekh and Lewin, 2005). Accordingly we used SPSS software for data processing, and run descriptive analysis, correlation analysis, and crosstabular analysis, to study the value and status of each indicator and the relationship between them. Results were scored between 0 and 200 so that each indicator got a score between 0 (lowest) and 200 (highest) showing the value of the indicators. This also discovered areas of concern and problem; the lowest indicators had the higher priority for any neighbourhood improvement strategy.

\section{Table 1 Here: Table 1: Social Sustainability Pillars, Indicators, and Measures}

Understanding the 'neighbour' pillar was achieved through available data such as census data and local surveys, and a more refined data collected from the questionnaires regarding the household status, length of residency, place of birth of household members, household type and ownership, etc.

To attain a comprehensive picture of the social sustainability of Bethnal Green and gain a more refined understanding we conducted a cross-pillar analysis to identify any possible correlation and association between different indicators. Finally, the practical implications derived from the cross-pillar analysis paved the way for developing a 'Social Sustainability Enhancement Index' (SSEI) which consists of a set of recommendations in three areas of 'neighbourhood', 'neighbouring', and 'neighbours' in order to improve basic qualities of social sustainability. This holistic index which is site-specific has policy, planning, and design recommendations, and thus covers a range of actions from strategic planning to small-scale changes interventions for the Bethnal Green neighbourhood.

It is important to note that while we have not aimed for wider generalisation, the application of this multimethod approach with complementary qualitative and quantitative data gathering and analysis provide us with illustrative but extensive and robust data for better understanding of social sustainability indicators in the case study area. These can inform debate and policy and 
provide the foundation for follow up and more expanded research in future. Nevertheless, we do acknowledge the limitations already noted and in light of the experience gained from this study will provide reflections on further refinement and improvement of the approach for future research in the concluding section of this paper.

\section{Social Sustainability of Bethnal Green}

\subsection{Bethnal Green, Overview}

The case study area in Bethnal Green (35.7 ha) is located in the London Borough of Tower Hamlet, Bethnal Green North Ward. It is bounded by the Bethnal Green Road, Hackney Road, Cambridge Heath Road, and Warner Place and Squirries Street (see Fig. 1). The case study area was extensively built in the mid $19^{\text {th }}$ century, but suffered from underemployment and decline, making it the poorest parish of London in 1871 (Baker, 1998). Towards the end of $19^{\text {th }}$ century Bethnal Green turned into the heart of the East End and a destination for the displaced people from all over Britain and the world, leading to overcrowding associated with poverty and deprivation (Porter, 1996). An intensive clearance scheme was implemented in 1920s and 1930s (Baker, 1998). Damaged during the Second World War, the area was radically re-developed through erecting new estates and residential complexes. This culminated in a significant growth in the living standards and relative economic security (Butler and Rustin, 1996), and creation of a homogeneous society of mainly English working class in 1950s with strong local loyalties, family ties, and a matriarchal family structure (Young and Willmott, 1957). From 1980s onwards, Bethnal Green was slowly transforming into a socially and culturally diverse community (Rix, 1996), mainly due to the flow of immigration, particularly Pakistanis and later Bangladeshis (Pollen, 2002). A recent study shows that the area has been developed into a multi-ethnic neighbourhood (Dench et al., 2006).

Fig. 1 Here: Bethnal Green case study area

\subsection{Analysis: 'neighbours', 'neighbourhood', and 'neighbouring' in Bethnal Green}

\subsection{1 'Neighbours' in Bethnal Green}

Data from the national census and household survey suggests that the case study area has around 6,815 inhabitants, accommodated in around 2620 dwellings of different types from flats to terraced houses. Around 386 persons live in the participating households. Table 2 provides details of the participant households. They are from different ethnic backgrounds, Bangladeshis making 36.7 per cent of the population, which is higher than Bangladeshi population of the Tower Hamlet Borough (32 per cent) and far larger than population across London ( 3 per cent) 
or England (less than 1 per cent). In terms of household size, households with 6 person and more are 23.2 per cent which shows relatively large size families. The mean household size is 2.60 which is slightly higher than the average household size in London (2.47 in 2011), Borough of Tower Hamlet (2.48 in 2011), and the Bethnal Green North ward (2.50 in 2011) where the study area is located (Greater London Authority, 2015; Tower Hamlet, 2012, p. 4). This is due to concentration of council estates and family structure in the study area. Home ownership is 32.1 per cent, owned outright or with a mortgage. Accommodations are mainly rented, mostly from the public sector (47.4 per cent). The average residency length in the current flat is 13.4 years while residency in the neighbourhood is 19.11 years. The average bedroom number is 2.97. 4-wheel vehicle ownership is 47 per cent (55 per cent in London in 2011), 67 per cent of households have no bicycle.

Table 2 here: Table 2: 'neighbour' profile of the participant households.

\subsection{2. 'Neighbourhood' in Bethnal Green}

The area has a population density of 190.8 person per hectare (pph) which is higher than the average in Bethnal Green North Ward (166.3 pph). This is due to several council estates located in the area consisting of middle to high-rise buildings. Around 17 per cent of plots are mixed use, mainly concentrated along Bethnal Green Road, Cambridge Heath Road and Hackney Road, or in the heart of the area around Winkley Street where historical buildings of mixed land use (workshops and accommodation) are located.

The area is well served by the over ground train (Cambridge Heath Station, Lea Valley Lines) and London Tube (Bethnal Green Station, central line), and several bus routes ( 7 bus stops). There is no cycling path across the streets. Space Syntax analysis (Fig. 2) shows that at the city scale the Old Bethnal Green Road, Hackney Road, Cambridge Heath, and Bethnal Green Road are the most integrated streets, but at the local scale the Old Bethnal Green Road is a significant movement axis. This implies that, spatially, the intersection of the Old Bethnal Green Road and Canrobert Street is a potential focus point for the neighbourhood. However, Bethnal Green Road which is densely accommodated by diverse types of shops and other land uses remains the main local and regional hub. Overall, the majority of the buildings are flats ( 88 per cent). Also $34 \%$ of buildings are 3 -storey height, followed by 2 -storey buildings (20 per cent) and 4 storey buildings (18 per cent).

Fig. 2 Here: Space Syntax Analysis of choice (movement flows). Left: Normalised choice (radius 10,000); Right: Normalised choice (radius 200) 


\subsection{3. 'Neighbouring' in Bethnal Green}

Descriptive analysis of the household survey provides us with detailed information regarding 'neighbouring' activities and indicators. To provide focus in the limited confines of this paper, we review only 3 indicators of accessibility, social interaction and networking, and participation. However, to assist with better understanding of broader debate we present summary tables for the other indicators. The neighbourhood benefits from high accessibility: overall, 82.6 per cent of the participants walk to reach basic urban services, from corner shop and post office to library and schools (see: Table 3). Cycling is the least used mean (3.1 per cent).

\section{Table 3 Here: Overall accessibility of urban services}

In terms of social interaction and networking, on average, participants know 5.29 neighbours by name which is higher than average in the UK which is 4 (AVIVA, 2017). 44.9 per cent of the participants meet and chat with their neighbours every day or at least two times per week. On average, participants have 7.34 friends in the neighbourhood. 21 per cent of the participants have no friend. While 10.6 per cent always ask their neighbours for help, 56.4 per cent of them are likely to ask for help. 42.1 per cent of the participants exchange help with neighbours now and then, 8.4 per cent very often, 27.4 per cent never.

The average number of community-based organisations known by the participants in their neighbourhood is 3.1. However, 77.1 per cent of them are not members of any communitybased organisation. Around half of the participants (49 per cent) never attend any religious activities and 24 per cent only occasionally. People rate the will of local authorities in involving citizens in decision making processes as very low (25 per cent) and low (21.7 per cent). However, they are aware that they do not actively participate in any consultation request coming from the local authority (39.6 per cent rate their response as very low, 20.9 per cent as low). Overall, participants' involvement in addressing neighbourhood issues and problems is low: 34.7 per cent of the participants rate it as very low and 25.3 per cent as low.

An overview of other neighbouring indicators could be found in the Tables 4-7. We asked all the participants to weight each indicator based on their importance and significance from 1 (lowest) to 5 (highest). As Table 8 suggests, quality of home, safety and security, and access to facilities are the most important indicators for social sustainability from the inhabitants' perspective, while participation is the least important indicator, interaction and networking being the second lowest. 
Table 5 Here: Sense of attachment

Table 6 Here: Satisfaction with neighbourhood

Table 7 Here: Satisfaction with home

Table 8 Here: Weight of indicators by participants

Table 9 shows the overall value of each indicator in the eyes of the inhabitants scored in a range between 0 (lowest) and 200 (highest). This informative table suggests that access to facilities has the highest value, safety and security the second highest. The lowest value is for participation in the neighbourhood, interaction and networking is the second lowest. A comparison between Tables 8 and 9 provides us with some interesting insights into the life of residents. For example, two indicators of 'interaction and networking' and 'participation in neighbourhood' have the lowest grade which indicates that participants consider them as the least valuable element. Quality of home has the highest weight for the participants, but their actual perception of home (having the value of 126.3) implies that the quality of their homes is far from their expectations. Since the 'values of indicators' are positioned between 0 and 200, they show which indicators have the lowest standard in the eyes of residents and thus need more attention. As will be discussed later, this provides policymakers and practitioners with valuable first-hand knowledge to address real concerns of the inhabitants in their programmes and initiatives.

Table 9 Here: Value of indicators

\subsubsection{Cross-pillar Analysis}

Reading and analysing data collected from each pillar against each other provides us with more holistic insights into the social sustainability of Bethnal Green. In the following, we briefly review some of these explorations. Overall, the Bethnal Green study area presents itself as a socially, ethnically, and religiously mixed community, with a relatively high presence of Bangladeshi people concentrated over the last couple of decades. A slightly higher household size (2.60 compared to the London of 2.47) reflects the family tradition of minorities in having larger families. There is also a mix of tenures, but a high percentage of the rented accommodations (47.4 per cent) are from public sector. This is because of the large-scale council estate and social housing developments that exist across the neighbourhood, which coupled with the higher household size make the area densely populated (population density 
190.8 person per hectare) compared to the Bethnal Green North Ward (166.3 person per hectare).

Despite the low level of mixed land use (only 17 per cent) and high assemblage of residential land use inside the case study area, basic urban facilities are mainly located within walking distance, largely situated across bordering southern, eastern, and northern streets. Cycling is the least used means for transportation (Table 3). This reflects the low share of cycling mode in London which was only about 2 per cent in 2015 (Transport for London, 2016) despite recent increase in cycling rate (Transport for London, 2016; Steinbach et al., 2011). Similar to England - 42 per cent bicycle ownership (Department for Transport, 2017) - the household survey shows that 67 per cent of households have no bicycle which implies the low level of interest in cycling. At the same time previous site analysis shows there is no designated cycling path within the neighbourhood area. Such a lack may partly explain the relatively low cycle ownership since as Garrard (2003) identifies it would make cycling unsafe and uncomfortable.

The average number of neighbours known by name (5.29) which is higher than UK average (4), and the average number of friends in the neighbourhood (7.34) shows a relatively higher level of social relationship among inhabitants. This could be partly due to spatial structure of the neighbourhood which comprises of estates and residential complexes, as well as strong familial social structure (one-person household is only 14.7 per cent) particularly within the minority groups (Dench et al., 2006). The level of assistance and conversing between neighbours is not very high, but in an era of decreasing social interactions and increasing weak ties (Blokland, 2003; Putnam, 2000; Henning and Lieberg, 1996) one observes a relatively engaged level of social interaction.

While land use maps (neighbourhood pillar) show a relatively high number of active community-based organisations that potentially provide space for citizen involvement and participation - there are 2 Churches, one Mosque, one Islamic Centre, and 5 active community space such as Minerva Community Centre, Zander Court and Kedleston Walk within the neighbourhood area - neighbourhood participation has the lowest value of 'neighbouring' pillar (see Table 9). According to the household survey, participants know on average 3.1 communitybased organisations within the neighbourhood, but 77.1 per cent are not members of any of them. The survey did not measure their possible involvement organizations outside neighbourhood. These facts indicate that the low level of neighbourhood participation is not peculiar to the case of Bethnal Green, but mirrors a global trend and is a world-wide challenge (Lane, 2005; Irvin and Stansbury, 2004). 
A large number of literature (Karuppannan and Sivam, 2011; Dave, 2011; Howley et al., 2009), as well as UK-based research (Dempsey, et al., 2012; Bramley and Power, 2009; Bramley et al., 2009) show a negative correspondence between density and perception of home and neighbourhood quality. However, despite a compact urban structure and high population density, home and neighbourhood satisfaction in Bethnal Green is relatively high (see Tables 5 and 7). Apartments with average bedroom number of 2.97 provide enough space for families; and occupiers are satisfied with neighbours. Middle-rise building pattern with generous space between blocks provides some space for greenery and also off-street parking places, so that participants show low level of dissatisfaction with parking space in Bethnal Green. The longer neighbourhood residency (19.11 years) compared to home residency (13.4 years) suggests that people would like to stay in the same area, though they may have to change their house for different reasons. The household survey shows that 69.8 per cent of participants have no plan to move out of their neighbourhood, naming good quality of neighbourhood (26.8 per cent), satisfaction with neighbours (26.8 per cent), and job reasons (17.1 per cent) as the main reason. Job reasons (16.2 per cent) and poor quality of neighbourhood (13.5 per cent) are the main reasons for those who want to move out. Moreover, 70.3 per cent of participants have no plan to change their home. Having sufficient space at home (24.8 per cent), good quality of home (18.4 per cent), being satisfied with the neighbourhood (16.8 per cent), and non-affordability of moving to a better and bigger home (14.4 per cent) are the main reasons for not changing the home. Those who plan to change their home refer to the lack of sufficient space at home (57.6 per cent) and poor quality of home (18.2 per cent) as the main reasons for their intentions.

\subsubsection{Social Sustainability Enhancement Index}

Our analysis of the social sustainability of Bethnal Green provided us with an in-depth insight into three aspects of 'neighbours', 'neighbourhood' and 'neighbouring'. It identified areas of strength and weakness, explored areas of concern from the inhabitants' perspective, and suggested priorities. This body of first-hand knowledge can serve as a platform for making practical policy, planning, and design recommendations through which the social sustainability value of the study area could be improved. These suggestions, derived from the analysis of the household survey and informed by the literature and research studies, are integrated into a Social Sustainability Enhancement Index (SSEI) which could serve as a guideline for future development plans. This index and proposed recommendations could not be statistically generalised and are not necessarily applicable to other neighbourhoods: for each neighbourhood we need to develop a specific SSEI derived from the careful application of the proposed evaluation framework. Nevertheless, we feel it does add to the debate at a conceptual and policy 
level, and provides a basis for further work in Bethnal Green and developing more bespoke indices in other neighbourhoods. The SSEI will be formulated in three sections of SSEINeighbour, SSEI-Neighbourhood, and SSEI-Neighbouring.

The main policy to enhance the 'neighbour' pillar would be implementing policies which safeguard the social mix and diversity of the neighbourhood which have been achieved during the last couple of decades. This neighbourhood, following Galster's formula (Galster, 1998), is considered as mixed neighbourhood as no single group makes up more than 75 per cent of the population. Intensifying mixed land use (Rowley, 1996), improving quality of neighbourhood (Yinger, 1995), controlling gentrification and minimising displacement (Talen, 2006; Lelévrier, 2013) could be suggested as proper policies for maintaining and balancing social mix. However, challenges of mixed communities, for example the problem of 'parallel lives' should not be underestimated: the literature suggests that social mix does not necessarily lead to social cohesion and integration, but people may leave 'parallel lives' with no significant social interaction between inhabitants of different ethnicity, race, religion, social class, etc. (Samad, 2013; Camina and Wood, 2009; Robinson, 2007). This highlights the need for implementing policies which provide opportunities for interaction between socially and culturally different inhabitants. We would label this as SSEI-Neighbouring.

A summary of key relevant findings and our suggestions for SSEI-Neighbourhood and SSEINeighbouring have been summarised in tables 10 and 11. Suggestions are made in two categories of policy and planning, and design. The former underlines policy strategies and the latter provides design-oriented recommendations. Both of these can potentially be included in future developments. It should be noted, however, that some of the policy and design recommendations are indirectly induced from the field data in the context of our wider debate including cross-pillar analysis as well as literature and policy reviews. For example, in terms of density, as noted, the study area has higher population density than the average Bethnal Green Ward, because of the family tradition, larger household size, and the mid-rise to high-rise buildings. There is no empty land, and it is unlikely to achieve much higher population and building densities, unless infill development is used as a tool for densification after careful examination of its socio-economic and environmental consequences (Thomas and Cousins, 1996; Schmidt-Thomé et al., 2013). There are some empty buildings which could be refurbished for residential and non-residential purposes, which may lead to a slightly higher population and building density. Another significant improvement could happen around the intersection of Old Bethnal Green Road and Canrobert Street to serve as the neighbourhood centre and communal space (Lelévrier, 2013), taking into account the capacity of Middleton 
Park as a large green space with play grounds, a number of shops on the northern border of the park, and the Winkley Estate area with traditional mixed land use (workshop and residential units). This scheme should also include some actions such as: dedicating some shops to collective neighbourhood-oriented activities such as youth centres or voluntary training; enhancing quality of green space and upgrading existing playing facilities; holding regular community-based social activities; and accommodating communal activities such as community gardening.

\section{Table 10: SSEI-Neighbourhood}

Enhancing social interaction and networking as the second lowest indicator of 'neighbouring' pillar is one of the key but challenging parts of the SSEI-Neighbouring. The average number of neighbours known by name (5.29) which is higher than UK average (4), and the average number of friends in the neighbourhood (7.34) indicates that social ties, more likely due to familyoriented, multi-ethnical structure of the neighbourhood (Dench et al., 2006), link people together. This may be in part related to the social and ethnic mix of the neighbourhood which would support Young's (1990) assertion that social diversity and multi-ethnical structure should be safeguarded, and even encouraged. However, the phenomenon of 'parallel lives,' as noted earlier, should not be underestimated. Taking into account that Bethnal Green is a socially mixed community, a potential reason for low interaction and networking could be the 'parallel lives' within the community which hinders significant social interaction between inhabitants of different ethnicity, race, religion, social class, etc. In-depth and holistic ethnographic studies need to be conducted to investigate to what extent the phenomenon of 'parallel lives' affects level of social interaction and networking in the area. However, comparing the results of the household survey with available data in the UK (Office for National Statistics, 2017) indicates that, overall, social interaction and networking criteria are not lower than UK average and this suggests that the low level of social interaction and networking is a general, and globally observable, trend reflecting the nature of modern urban life, particularly at the neighbourhood scale (Blokland, 2003; Putnam, 2000; Guest and Wierzbicki, 1999; Henning and Lieberg, 1996). However, a number of measures could help promote social interaction and networking at the neighbourhood scale including promoting communal activities such as communal gardening and community-oriented gatherings such as local festivals and club meetings to intensify social interaction and connectedness (Alaimo et al., 2010; Comstock et al., 2010), stimulating mixed land use policy to enhance social engagement and face-to-face interaction in public spaces and streets (Leyden, 2003), upgrading the areas around the Middleton Park towards a functioning neighbourhood hub as explained before, and improving quality of open 
and green spaces to make them safer, more comfortable, and more attractive places for the inhabitants to use for socialising (Williams, J., 2005; Leyden et al., 2011)(Williams, J., 2005; Leyden et al., 2011). These measures could also potentially establish and activate weak ties and provide relational bridges to the networks within the neighbourhood (Chaskin and Joseph, 2011). Two remarks need to be made here. First, the scale and intensity of mixed use should be carefully considered while planning for mixed use strategies. Our recommendations are in line with the findings of Evans et al. (2009) that developing large scale concentrated mixed use blocks at the local scale may produce less successful and sustainable environments. They suggest a more scattered and heterogeneous mixed use pattern, and our recommendations, taking into account urban layout and building typology of the central Bethnal Green, follow such a pattern. Secondly, we are aware that physical interventions do not necessarily lead to predicted social consequences and thus are not advocating an 'environmental deterministic' argument, i.e., that there is a great correspondence between spatial design and social life (Lang, J. T., 1987). On the contrary, our recommendations advocate the 'opportunistic' argument that suggests physical environment only provides or precludes opportunities for interaction and socialisation; it creates the field of probable encounter and co-presence (Hillier, 1989, p. 13).

Neighbourhood inhabitants' concerns regarding feelings of safety, derived from household survey, have some planning and policy implications. To achieve higher safety for children on the street a comprehensive traffic management plan should be developed and integrated into the future local plan which includes traffic calming measures and dedicated pathways for cycling (Wheeler, 2013). A more efficient police presence is also expected by the participants (42.4 per cent of the participants rate the police presence as fairly weak, 13.1 per cent as very weak). A main consequence of mixed land use policy would be higher natural surveillance (Welsh and Farrington, 2009). Developing policies which protect public and private tenancy contracts and secure long-term residency can enhance feeling of neighbourhood attachment (Brown et al., 2003).

Table 11 Here: SSEI-Neighbouring

\section{Conclusion: Research and Policy Implications}

Debates on socially sustainable neighbourhoods, as noted, is gaining growing significance in both research and policy arenas. To contribute to this debate, building on existing studies that explore different aspects of social sustainability and propose relevant indicators for measurement purposes, we developed a tripartite framework that promises a more qualitative understanding from social sustainability, paves the way to an intersectional analysis of the 
indicators, and can help policy-makers and designers to identify existing weaknesses and challenges in a given context and come up with relevant, context-oriented recommendations for improvement. This framework was applied to the case study of Bethnal Green and provided case specific policy and design recommendations. In the concluding section, we will elaborate these contributions, and explore areas of concern for further research.

The proposed definition maintains a balance between soft and hard aspects of socially sustainable neighbourhoods, or between perceived and conceived dimensions. If social sustainability of a neighbourhood is defined by the perception of the inhabitants of both physical and social qualities and indicators, then physical characteristics of the built environment (hard infrastructure) and social life of the inhabitants (social infrastructure) are constituent elements and components of socially sustainable neighbourhoods.

The proposed definition suggests a tripartite structure; social sustainability of urban neighbourhoods is intersection of three pillars of 'neighbourhood', 'neighbouring', and 'neighbours.' For each pillar we identified a set of indicators that are informed by the literature and existing studies in the related field and are place-specific (appropriate for urban neighbourhoods). The proposed definition and structure, thus, benefits from following characteristics: it is site-specific (addresses a specific neighbourhood), multi-dimensional and holistic (links conceived-perceived qualities), socio-spatial in nature, and primarily founded on qualitative data. This holistic and qualitative formulation of social sustainability at the neighbourhood scale advances previous studies that have been conducted, to some we referred earlier.

We further developed the proposed definition and structure to a 4-stage evaluation framework based on which the social sustainability level of a neighbourhood could be analysed. This framework is progressive and innovative in many ways. First, it is integrative and holistic, as it merges the three principal elements of 'neighbourhood', 'neighbouring' and 'neighbours'. As the literature suggests, the importance of inhabitants (neighbours) and the space of the urban setting (neighbourhood) has been widely overlooked in the social sustainability discourse. Secondly, it is site-specific as the defined indicators are most appropriate for the given neighbourhood. Thirdly, in line with the emerging 'research paradigm' which synthesises qualitative and quantitative methods and tools in order to provide "the most informative, complete, balanced, and useful research results" (Johnson et al., 2007, p. 29), and obtain "better understanding of the multifaceted and complex character of social phenomena" (Greene, 2008, p. 20), this research utilises a mixed methodology employing relevant quantitative and 
qualitative methods. Fourthly, the cross-pillar analysis we suggested provides us with in-depth and broad knowledge of different dimensions of social sustainability. Fifthly: the suggested scoring system helps us to explore how the participants rate the level of each indicator, which indicators have the highest and lowest scores, and thus which indicator needs more attention and improvement. And finally, the results of the analysis provide us with an indication for the measures needed to improve social sustainability standards for the Bethnal Green neighbourhood, what we referred to as Social Sustainability Enhancement Index (SSEI). The application of the proposed evaluation methodology to the case of Bethnal Green helped us acknowledge the strength, potential, and competencies of the proposed framework, but at the same time explore some of its weaknesses and shortcomings. It should be underlined that recommendations given in the form of SSEI in this paper are place-specific and relevant to the study area, not statistically generalizable and not applicable to other neighbourhoods. Yet, they do provide extensive illustrative evidence to enable a robust analysis in combination with other employed methods and provide a basis for further work both in Bethnal Green and other neighbourhoods. Undoubtedly, some methodological revisions, we would argue, will make the proposed framework more promising, integrative, and informative.

First of all, the proposed evaluation framework has been applied to one case study as a pilot; it needs to be tested in more diverse geographical, socio-cultural, and spatial settings worldwide. This will identify its problems and shortcomings, and help us find solutions to fill the methodological gaps. This pilot project identified one main shortcoming of the proposed framework which is its inability in clarifying some essentially qualitative questions. For example, our 4-stage framework was not properly designed to address the existence or nonexistence of 'parallel lives' in Bethnal Green, the idea that people delimit their social interaction and networks to the people of the same class (Camina and Wood, 2009; Robinson, 2007; Phillips, 2006). As noted earlier, the census data suggests that Bethnal Green is currently a socially-mixed community. The household survey we designed to investigate different 'neighbouring' patterns did not include questions for investigating 'social interaction and networking' between different inhabitants in terms of ethnicity, race, religion, and wealth. In fact, our household survey indicates a low level of 'social interaction and networking', but is unable to show if this is because of the phenomenon of 'parallel lives', or has other reasons. More ethnographic studies would be able to address this shortcoming. We suggest restructuring the framework to a 5-stage process so that some qualitative inputs (for example ethnographic interview with inhabitants and transect walking with community members) dig into the life- 
work of the inhabitants and shed light into latent aspects of the social life on the one hand, and find clarifications for the outcomes of the household survey, on the other.

The proposed definition and framework also carries significant policy and design implications. On the policy level, the proposed framework can be employed by the local authorities to assess social sustainability of urban neighbourhoods, identify areas of challenge and concern, and consider them in future development and improvement plans. This necessitates conducting a survey; the costs and administration of which should be considered in the annual programmes and budgets. A broader comparative analysis of different neighbourhood types in different social and geographical contexts can show which types of neighbourhoods are socially more sustainable. This provides decision makers with some hints for directing future urban developments. In urban (re)development projects, such as neighbourhood regeneration programmes, the suggested evaluation framework can be an integral part of the planning, implementation and monitoring strategy of the project. Accordingly, at the early stages of design, the results of the evaluation can be used as a guideline for planning and design, while during the implementation of the projects and after the completion they can serve as a reference to monitor the changes of indicators. Overall, policy makers should note that there is a social sustainability aspect for any sustainable future which is less recognized but is vital and needs to be addressed in any urban (re)development agenda.

Finally, the normative nature of social sustainability discourse needs further critical investigation. In fact, questioning normativity of planning interventions implies asking questions about the meaning of 'better' (Healey, 2012), and this necessitates asking metaethical questions, for example the nature and meaning of normative values in a situated context, and planners' ability in achieving an appropriate interpretation from them (Winkler and Duminy, 2016). Our proposal tries to understand how residents weight social sustainability values (what we defined as indicators), and prioritizes them based on their opinion, and thus goes, to some extent, beyond the normativity of social sustainability discourse. However, we would admit that the defined indicators are essentially informed by the literature and thus are normative in nature. To reduce the normative nature of social sustainability discourse based on situated contexts we would suggests involving neighbourhood residents in defining and identifying relevant indicators, using appropriate methods such as surveys or focus groups discussions. This will exclude new-built neighbourhoods that have no neighbours, but will make social sustainability indicators, and consequently, the evaluation framework, more placespecific. We end on this note as the way forward for future research. 


\section{References:}

Alaimo, K., Reischl, T. M. and Allen, J. O. (2010) Community gardening, neighborhood meetings, and social capital. Journal of Community Psychology 38.4, 497-514.

Alcock, P. (2004) Participation or Pathology: Contradictory Tensions in Area-Based Policy. Social Policy and Society 3.2, 87-96.

Allred, S. B. and Ross-Davis, A. (2011) The Drop-off and Pick-up Method: An Approach to Reduce Nonresponse Bias in Natural Resource Surveys. Small-scale Forestry 10.3, 305-18.

Argyle, M. (2007) Social Interaction. Transaction Publishers.

Austin, D. M., Furr, L. A. and Spine, M. (2002) The effects of neighborhood conditions on perceptions of safety. Journal of Criminal Justice 30.5, 417-27.

AVIVA (08/08/2017) UK: Six million UK adults don't know any of their neighbours by name. [WWW document]. URL https:/www.aviva.co.uk/media-centre/story/17786/sixmillion-uk-adults-dont-know-any-of-their-neigh/.

Bacon, N., Cochrane, D. and Woodcraft, S. (2012) Creating Strong Communities. How to measure the social sustainability of new housing developments. London: The Berkeley Group.

Baker, T. F. T. (1998) A History of the County of Middlesex: Volume 11, Stepney, Bethnal Green. British History Online, London.

Bargh, J. A. and McKenna, K. Y. A. (2004) The Internet and Social Life. Annual Review of Psychology 55.1, 573-90.

Barreira, A. P., Agapito, D., Panagopoulos, T. and Guimarães, M. H. (2016) Exploring residential satisfaction in shrinking cities: a decision-tree approach. Urban Research \& Practice 1-22. doi:10.1080/17535069.2016.1179784.

Barton, H. (2000a) Conflicting Perceptions of Neighbourhood. In Barton, H. (ed.), Sustainable Communities, The Potential for Eco-Neighbourhoods. Earthscan, London.

Barton, H. (2000b) Urban Form and Locality. In Barton, H. (ed.), Sustainable Communities, The Potential for Eco-Neighbourhoods. Earthscan, London.

Barton, H., Grant, M. and Guise, R. (2010) Shaping Neighbourhoods for Local Health and Global Sustainability. Routledge, London and New York.

Bennett, G. G., McNeill, L. H., Wolin, K. Y., Duncan, D. T., Puleo, E. and Emmons, K. M. (2007) Safe To Walk? Neighborhood Safety and Physical Activity Among Public Housing Residents. (Duperrex, O., ed.)PLoS Medicine 4.10, e306.

Blokland, T. (2003) Urban Bonds. Wiley.

Boschmann, E. E. and Kwan, M.-P. (2008) Toward Socially Sustainable Urban Transportation: Progress and Potentials. International Journal of Sustainable Transportation $2.3,138-57$.

Bradley, Q. (2017) Neighbourhood planning and the impact of place identity on housing development in England. Planning Theory \& Practice 18.2, 233-48.

Bramley, G., Dempsey, N., Power, S., Brown, C. and Watkins, D. (2009) Social sustainability and urban form: evidence from five British cities. Environment and Planning A 41.9, 2125 42 .

Bramley, G. and Power, S. (2009) Urban form and social sustainability: the role of density 
and housing type. Environment and Planning B: Planning and Design 36.1, 30-48.

Brignall, T. W. and Van Valey, T. (2005) The Impact of Internet Communications on Social Interaction. Sociological Spectrum 25.3, 335-48.

Brindley, P., Goulding, J. and Wilson, M. L. (2018) Generating vague neighbourhoods through data mining of passive web data. International Journal of Geographical Information Science 32.3, 498-523.

Brounen, D., Cox, R. and Neuteboom, P. (2012) Safe and Satisfied? External Effects of Homeownership in Rotterdam. Urban Studies 49.12, 2669-91.

Brown, B., Perkins, D. D. and Brown, G. (2003) Place attachment in a revitalizing neighborhood: Individual and block levels of analysis. Journal of Environmental Psychology 23.3, 259-71.

Brownill, S. and Bradley, Q. eds. (2017) Localism and neighbourhood planning: Power to the people? 1 edition. Policy Press.

Brownill, S. and Carpenter, J. (2009) Governance and 'Integrated' Planning: The Case of Sustainable Communities in the Thames Gateway, England. Urban Studies 46.2, 251-74.

Burton, E. (2000a) The Potential of the Compact City for Promoting Social Equity. In Williams, K., E. Burton and M. Jenks (eds.), Achieving Sustainable Urban Form. Routledge, London; New York.

Burton, E. (2000b) The Compact City: Just or Just Compact? A Preliminary Analysis. Urban Studies 37.11, 1969-2006.

Byun, G. and Ha, M. (2016) The Factors Influencing Residential Satisfaction by Public Rental Housing Type. Journal of Asian Architecture and Building Engineering 15.3, 535-42.

Camina, M. M. and Wood, M. J. (2009) Parallel Lives: Towards a Greater Understanding of What Mixed Communities Can Offer. Urban Studies 46.2, 459-80.

Campbell, H. (2012) Planning to Change the World: Between Knowledge and Action Lies Synthesis. Journal of Planning Education and Research 32.2, 135-46.

Carver, A., Timperio, A. and Crawford, D. (2008) Playing it safe: The influence of neighbourhood safety on children's physical activity-A review. Health \& Place 14.2, $217-$ 27.

Chan, E. and Lee, G. K. L. (2007) Critical factors for improving social sustainability of urban renewal projects. Social Indicators Research 85.2, 243-56.

Chaskin, R. J. and Joseph, M. L. (2011) Social Interaction in Mixed-Income Developments: Relational Expectations and Emerging Reality. Journal of Urban Affairs 33.2, 209-37.

Chatterton, P. and Bradley, D. (2001) Bringing Britain Together? The limitations of areabased regeneration policies in addressing deprivation. Local Economy 15.2, 98-111.

Chiu, R. L. H. (2003a) Social sustainability, sustainable development and housing development. In Forrest, R. and J. Lee (eds.), Housing and Social Change, East-West Perspectives. Routledge, London, New York.

Chiu, R. L. H. (2003b) Social sustainability, sustainable development and housing development. In Forrest, R. and James Lee (eds.), Housing and Social Change: East-West Perspectives. Routledge, London and New York.

Chiu, R. L. H. (2004) Socio-cultural sustainability of housing: a conceptual exploration. Housing, Theory and Society 21.2, 65-76. 
Christensen, P. and O'Brien, M. (2003) Children in the City: Home Neighbourhood and Community. Routledge, London; New York.

Clark, W. A. and Finley, J. C. (2007) Contracting Meter Readers in a Drop-Off/Pick-Up Survey in Blagoevgrad, Bulgaria. Society \& Natural Resources 20.7, 669-73.

Cochrane, A. (2012) Sustainable communities and English spatial policy. In The Future of Sustainable Cities: Critical Reflections. Policy Press, Bristol.

Colantonio, A. and Dixon, T. (2011) Urban Regeneration and Social Sustainability: Best Practice from European Cities. Wiley-Blackwell, Chichester, West Sussex, UK ; Hoboken, NJ.

Comstock, N., Miriam Dickinson, L., Marshall, J. A., Soobader, M.-J., Turbin, M. S., Buchenau, M. and Litt, J. S. (2010) Neighborhood attachment and its correlates: Exploring neighborhood conditions, collective efficacy, and gardening. Journal of Environmental Psychology 30.4, 435-42.

Cooper, R., Evans, G. and Boyko, C. (2009) Designing Sustainable Cities. John Wiley \& Sons.

Coulton, C. J., Jennings, M. Z. and Chan, T. (2013) How big is my neighborhood? Individual and contextual effects on perceptions of neighborhood scale. American Journal of Community Psychology 51.1-2, 140-50.

Cuthill, M. (2010) Strengthening the 'social' in sustainable development: Developing a conceptual framework for social sustainability in a rapid urban growth region in Australia. Sustainable Development 18.6, 362-73.

Dale, A. and Newman, L. (2010) Social capital: a necessary and sufficient condition for sustainable community development? Community Development Journal 45.1, 5-21.

Dave, S. (2010) High Urban Densities in Developing Countries: A Sustainable Solution? Built Environment 36.1, 9-27.

Dave, S. (2011) Neighbourhood Density and Social Sustainability in Cities of Developing Countries. Sustainable Development 19.3, 189-205.

Davidson, M. (2010) Social Sustainability and the City. Geography Compass 4.7, 872-80.

Davoudi, S. and Madanipour, A. (2015) Reconsidering localism. Routledge, New York and Abingdon.

Dekker, K. (2007) Social Capital, Neighbourhood Attachment and Participation in Distressed Urban Areas. A Case Study in The Hague and Utrecht, the Netherlands. Housing Studies 22.3, 355-79.

Dempsey, N., Bramley, G., Power, S. and Brown, C. (2011) The social dimension of sustainable development: Defining urban social sustainability. Sustainable Development 19.5, 289-300.

Dempsey, N., Brown, C. and Bramley, G. (2012) The key to sustainable urban development in UK cities? The influence of density on social sustainability. Progress in Planning 77.3, 89141.

Dempsey, N., Brown, C., Raman, S., Porta, S., Jenks, M., Jones, C. and Bramley, G. (2010) Elements of Urban Form. In Jenks, M. and C. Jones (eds.), Dimensions of the Sustainable City: 2. Springer.

Dench, G., Gavron, K. and Young, M. (2006) The New East End: Kinship, Race and Conflict. Profile Books, London. 
Department for Transport (2017) National Travle Survey: England 2016.

Durose, C. and Lowndes, V. (2010) Neighbourhood Governance: Contested Rationales within a Multi-Level Setting - A Study of Manchester. Local Government Studies 36.3, 341-59.

Elkin, T., McLaren, D. and Hillman, M. (1991) Reviving the City: Towards Sustainable Urban Development. Continuum International Publishing, London.

Evans, G., Aiesha, R. and Food, J. (2009) Urban Sustainability: Mixed-Use or Mixed Message. In Cooper, R., G. Evans and C. Boyko (eds.), Designing Sustainable Cities. John Wiley \& Sons, Chichester, UK.

Foord, J. (2010) Mixed-Use Trade-Offs: How to Live and Work in a 'Compact City' Neighbourhood. Built Environment 36.1, 28-46.

Forrest, R. and Kearns, A. (2001) Social Cohesion, Social Capital and the Neighbourhood. Urban Studies 38.12, 2125-43.

Foster, S., Giles-Corti, B. and Knuiman, M. (2010) Neighbourhood design and fear of crime: A social-ecological examination of the correlates of residents' fear in new suburban housing developments. Health \& Place 16.6, 1156-65.

Galster, G. C. (2019) Making Our Neighborhoods, Making Our Selves. University of Chicago Press, Chicago ; London.

Greater London Authority (2015) Housing in London 2015. London: Greater London Authority.

Greene, J. C. (2008) Is Mixed Methods Social Inquiry a Distinctive Methodology? Journal of Mixed Methods Research 2.1, 7-22.

Greider, T. and Krannich, R. S. (1985) Neighboring Patterns, Social Support, and Rapid Growth: A Comparison Analysis from Three Western Communities. Sociological Perspectives 28.1, 51-70.

Grosvenor, M. and O'Neill, P. (2014) The Density Debate in Urban Research: An Alternative Approach to Representing Urban Structure and Form: The Density Debate in Urban Research. Geographical Research 52.4, 442-58.

Guest, A. M. and Wierzbicki, S. K. (1999) Social Ties at the Neighborhood Level: Two Decades of GSS Evidence. Urban Affairs Review 35.1, 92-111.

Hamiduddin, I. and Adelfio, M. (2019) Social sustainability and newneighbourhoods: case studies from Spain and Germany. In Shirazi, M. R. and R. Keivani (eds.), Urban Social Sustainability: Theory, Policy and Practice. Routledge, London; New York.

Harris, T. and Weiner, D. (1998) Empowerment, Marginalization, and 'Communityintegrated' GIS. 25.2, 67-76.

Healey, P. (2012) The universal and the contingent: Some reflections on the transnational flow of planning ideas and practices. Planning Theory 11.2, 188-207.

Hempel, L. C. (1999) Conceptual and Analytical Challenges in Building Sustainable Communities. In Mazmanian, D. A. and M. E. Kraft (eds.), Toward Sustainable Communities: Transition and Transformations in Environmental Policy. MIT Press, Cambridge, Mass.; London.

Henning, C. and Lieberg, M. (1996) Strong ties or weak ties? Neighbourhood networks in a new perspective. Scandinavian Housing and Planning Research 13.1, 3-26.

Hillier, B. (1989) The architecture of the urban object. Ekistics 334-35, 5-21. 
Hillier, B. (1996) Space is the Machine: A Configurational Theory of Architecture. Cambridge University Press, Cambridge.

Hillier, B. (2002) A theory of the city as object: or, how spatial laws mediate the social construction of urban space. Urban Design International 7.3-4, 153-79.

Howley, P., Scott, M. and Redmond, D. (2009) Sustainability versus liveability: an investigation of neighbourhood satisfaction. Journal of Environmental Planning and Management 52.6, 847-64.

Irvin, R. A. and Stansbury, J. (2004) Citizen Participation in Decision Making: Is It Worth the Effort? Public Administration Review 64.1, 55-65.

Jabareen, Y. R. (2006) Sustainable Urban Forms Their Typologies, Models, and Concepts. Journal of Planning Education and Research 26.1, 38-52.

Jenks, M., Burton, E. and Williams, K. eds. (1996) The Compact City: A Sustainable Urban Form? Routledge, London; New York.

Jenks, M. and Dempsey, N. (2007) Defining the neighbourhood: Challenges for empirical research. Town Planning Review 78.2, 153-77.

Jenks, M. and Jones, C. (2010) Dimensions of the Sustainable City. Springer, Heidelberg. Johnson, R. B., Onwuegbuzie, A. J. and Turner, L. A. (2007) Toward a Definition of Mixed Methods Research. Journal of Mixed Methods Research 1.2, 112-33.

Karuppannan, S. and Sivam, A. (2011) Social sustainability and neighbourhood design: an investigation of residents' satisfaction in Delhi. Local Environment 16.9, 849-70.

Katz, J. E. and Rice, R. E. (2002) Social Consequences of Internet Use: Access, Involvement, and Interaction. MIT Press, Cambridge, Mass.

Kearns, A. and Parkinson, M. (2001) The Significance of Neighbourhood. Urban Studies $38.12,2103-10$.

Kennett, P. and Forrest, R. (2006) The neighbourhood in a European context. Urban Studies 43.4, 713-18.

Kraut, R., Brynin, M. and Kiesler, S. (2006) Computers, Phones, and the Internet: Domesticating Information Technology. Oxford University Press, Oxford.

Lafferty, W. M. (2014) Sustainable Communities in Europe. Earthscan, Abingdon, New York.

Landorf, C. (2011) Evaluating social sustainability in historic urban environments. International Journal of Heritage Studies 17.5, 463-77.

Landorf, C. (2019) Social sustainability and newneighbourhoods: case studies from Spain and Germany. In Shirazi, M. R. and R. Keivani (eds.), Urban Social Sustainability: Theory, Policy and Practice. Routledge, London; New York.

Lane, M. B. (2005) Public Participation in Planning: an intellectual history. Australian Geographer 36.3, 283-99.

Lang, J. T. (1987) Creating Architectural Theory: The Role of the Behavioral Sciences in Environmental Design. Van Nostrand Reinhold Company, New York.

Lang, R. (2019) Social sustainability as an urban agenda: Towards a comprehensive image. In Shirazi, M. R. and R. Keivani (eds.), Urban Social Sustainability: Theory, Policy and Practice. Routledge, London; New York.

Lawless, P. (2006) Area-based Urban Interventions: Rationale and Outcomes: The New Deal 
for Communities Programme in England. Urban Studies 43.11, 1991-2011.

Leal Filho, W., Platje, J., Gerstlberger, W., Ciegis, R., Kääriä, J., Klavins, M. and

Kliucininkas, L. (2016) The role of governance in realising the transition towards sustainable societies. Journal of Cleaner Production 113, 755-66.

Lees, L. (2014) The death of sustainable communities in London? In Sustainable London? The Future of a Global City. The Policy Press, Bristol.

Lee, S. M., Conway, T. L., Frank, L. D., Saelens, B. E., Cain, K. L. and Sallis, J. F. (2016) The Relation of Perceived and Objective Environment Attributes to Neighborhood Satisfaction. Environment and Behavior. doi:10.1177/0013916515623823.

Lelévrier, C. (2013) Social mix neighbourhood policies and social interaction: The experience of newcomers in three new renewal developments in France. Cities 35, 409-16.

Leyden, K. M. (2003) Social capital and the built environment: the importance of walkable neighborhoods. American Journal of Public Health 93.9, 1546-51.

Leyden, K. M., Goldberg, A. and Michelbach, P. (2011) Understanding the Pursuit of Happiness in Ten Major Cities. Urban Affairs Review 47.6, 861-88.

Lovejoy, K., Handy, S. and Mokhtarian, P. (2010) Neighborhood satisfaction in suburban versus traditional environments: An evaluation of contributing characteristics in eight California neighborhoods. Landscape and Urban Planning 97.1, 37-48.

Lowndes, V. and Sullivan, H. (2008) How Low Can You Go? Rationales and Challenges for Neighbourhood Governance. Public Administration 86.1, 53-74.

Manzi, T., Lucas, K., Jones, T. L. and Allen, J. eds. (2010) Social Sustainability in Urban Areas: Communities, Connectivity and the Urban Fabric. First edition. Routledge, London; Washington, DC.

Mazmanian, D. A. and Kraft, M. E. (1999) Toward Sustainable Communities: Transition and Transformations in Environmental Policy. MIT Press, Cambridge, Mass.; London.

McKenzie, S. (2004) Social Sustainability: Towards Some Definitions. Magill: Hawke Research Institute.

Michels, A. and De Graaf, L. (2010) Examining Citizen Participation: Local Participatory Policy Making and Democracy. Local Government Studies 36.4, 477-91.

Nasar, J. L. and Julian, D. A. (1995) The Psychological Sense of Community in the Neighborhood. Journal of the American Planning Association 61.2, 178-84.

Nedovic-Budic, Z., Knaap, G. J., Shahumyan, H., Williams, B. and Slaev, A. (2016) Measuring urban form at community scale: Case study of Dublin, Ireland. Cities 55, 148-64.

Netto, V. M., Keivani, R., Vargas, J. C. and de Saboya, R. T. (2019) The social effects of architecture: built from and social sustainability. In Shirazi, M. R. and R. Keivani (eds.), Urban Social Sustainability: Theory, Policy and Practice. Routledge, London; New York.

Office for National Statistics (/2017) Social Capital Headline Indicators. [WWW document]. URL

https://www.ons.gov.uk/peoplepopulationandcommunity/wellbeing/datasets/socialcapitalhead lineindicators (accessed 8th August 2017).

Oktay, D., Rüstemli, A. and Marans, R. W. (2009) Neighborhood satisfaction, sense of community, and attachment: Initial findings from Famagusta quality of urban life study. AIZ, ITU Journal of the Faculty of Architecture 6.1, 6-20. 
Opp, S. M. (2016) The forgotten pillar: a definition for the measurement of social sustainability in American cities. Local Environment 22.3, 286-305.

Pagano, M. A. (2015) The Return of the Neighborhood as an Urban Strategy. The University of Illinois, Chicago.

Parkes, A., Kearns, A. and Atkinson, R. (2002) What Makes People Dissatisfied with their Neighbourhoods? Urban Studies 39.13, 2413-38.

Park, Y. and Rogers, G. O. (2015) Neighborhood Planning Theory, Guidelines, and Research Can Area, Population, and Boundary Guide Conceptual Framing? Journal of Planning Literature 30.1, 18-36.

Peterson, N. (2016) Introducing to the special issues on social sustainability: integration, context, and governance. Sustainability: Science, Practice, \& Policy 12.1.

Phillips, D. (2006) Parallel Lives? Challenging Discourses of British Muslim Self-

Segregation. Environment and Planning D: Society and Space 24.1, 25-40.

Pollen, R. (2002) Bangladeshi Family Life in Bethnal Green. London School of Economics and Political Science, London.

Porter, R. (1996) London: a social history. Penguin, London.

Psarikidou, K. and Szerszynski, B. (2012) Growing the social: alternative agrofood networks and social sustainability in the urban ethical foodscape. Sustainability: Science, Practice \& Policy 8.1, 30-39.

Putnam, R. D. (2000) Bowling Alone: The Collapse and Revival of American Community. Simon \& Schuster, New York; London.

Raco, M. (2007) Securing Sustainable Communities Citizenship, Safety and Sustainability in the New Urban Planning. European Urban and Regional Studies 14.4, 305-20.

Raman, S. (2010) Designing a Liveable Compact City. Physical Forms of City and Social Life in Urban Neighbourhoods. Built Environment 36.1, 63-80.

Relph, E. (1976) Place and placelessness. Pion, London.

Robinson, D. (2007) Living Parallel Lives? Housing, Residential Segregation and Community Cohesion in England. In Beider, H. (ed.), Neighbourhood Renewal \& Housing Markets. Blackwell Publishing Ltd, Oxford, UK.

Rodenburg, C. A. and Nijkamp, P. (2004) Multifunctional Land Use in the City: A Typological Overview. Built Environment 30.4, 274-88.

Rogers, G. O. and Sukolratanametee, S. (2009) Neighborhood design and sense of community: Comparing suburban neighborhoods in Houston Texas. Landscape and Urban Planning 92.3-4, 325-34.

Roseland, M. (2012) Toward Sustainable Communities: Solutions for Citizens and Their Governments. New Society Publishers, Gabriola Island.

Rowley, A. (1996) Mixed-use Development: Ambiguous concept, simplistic analysis and wishful thinking? Planning Practice \& Research 11.1, 85-98.

Samad, Y. (2013) Community cohesion without parallel lives in Bradford. Patterns of Prejudice 47.3, 269-87.

Scheer, B. C. (2010) The Evolution of Urban Form: Typology for Planners and Architects. APA Planners Press, Washington, DC.

Schmidt-Thomé, K., Haybatollahi, M., Kyttä, M. and Korpi, J. (2013) The prospects for urban 
densification: a place-based study. Environmental Research Letters 8.2, 025020.

Shirazi, M. R. (2018) Mapping neighbourhood outdoor activities: space, time, gender and age. Journal of Urban Design 0.0, 1-23.

Shirazi, M. R. and Keivani, R. (2017) Critical reflections on the theory and practice of social sustainability in the built environment - a meta-analysis. Local Environment 22.12, 1526-45.

Shirazi, M. R. and Keivani, R. (2019a) Social sustainability as an urban agenda: Towards a comprehensive image. In Shirazi, M. R. and R. Keivani (eds.), Urban Social Sustainability: Theory, Policy and Practice. Routledge, London; New York.

Shirazi, M. R. and Keivani, R. (2019b) Spatiality of social sustainability: social activity and neighbourhood space. In Shirazi, M. R. and R. Keivani (eds.), Urban Social Sustainability: Theory, Policy and Practice. Routledge, London; New York.

Sirgy, M. J. and Cornwell, T. (2002) How Neighborhood Features Affect Quality of Life. Social Indicators Research 59.1, 79-114.

Skjaeveland, O., Gärling, T. and Maeland, J. G. (1996) A multidimensional measure of neighboring. American Journal of Community Psychology 24.3, 413-35.

Soini, K. and Birkeland, I. (2014) Exploring the scientific discourse on cultural sustainability. Geoforum 51, 213-23.

Somekh, B. and Lewin, C. eds. (2005) Research Methods in the Social Sciences. SAGE Publications Ltd, London; Thousand Oaks, Calif.

Stafford, M., Bartley, M., Sacker, A., Marmot, M., Wilkinson, R., Boreham, R. and Thomas, R. (2003) Measuring the Social Environment: Social Cohesion and Material Deprivation in English and Scottish Neighbourhoods. Environment and Planning A 35.8, 1459-75.

Steinbach, R., Green, J., Datta, J. and Edwards, P. (2011) Cycling and the city: A case study of how gendered, ethnic and class identities can shape healthy transport choices. Social Science \& Medicine 72.7, 1123-30.

Talen, E. (2003) Neighborhoods as Service Providers: A Methodology for Evaluating Pedestrian Access. Environment and Planning B: Planning and Design 30.2, 181-200.

Talen, E. (2006) Design for Diversity: Evaluating the Context of Socially Mixed Neighbourhoods. Journal of Urban Design 11.1, 1-32.

Teernstra, A. B. and Pinkster, F. M. (2016) Participation in neighbourhood regeneration: achievements of residents in a Dutch disadvantaged neighbourhood. Urban Research \& Practice 9.1, 56-79.

Thomas, L. and Cousins, W. (1996) The Compact City: A Successful, Desirable and Achievable Urban Form? In Jenks, M., E. Butron and K. Williams (eds.), The Compact City, A Sustainable Urban Form? E \& FN Spon, London.

Tower Hamlet (2012) Population and household estimates for Tower Hamlets Wards. London.

Transport for London (2016) Travel in London, Report 9. London: Transport for London.

Tsou, K.-W., Hung, Y.-T. and Chang, Y.-L. (2005) An accessibility-based integrated measure of relative spatial equity in urban public facilities. Cities 22.6, 424-35.

Walton, D., Murray, S. J. and Thomas, J. A. (2008a) Relationships Between Population Density and the Perceived Quality of Neighbourhood. Social Indicators Research 89.3, 40520 . 
Walton, D., Murray, S. J. and Thomas, J. A. (2008b) Relationships Between Population Density and the Perceived Quality of Neighbourhood. Social Indicators Research 89.3, 40520 .

Weingaertner, C. and Moberg, Å. (2014) Exploring Social Sustainability: Learning from Perspectives on Urban Development and Companies and Products. Sustainable Development 22.2, 122-33.

Welsh, B. C. and Farrington, D. P. (2009) Making Public Places Safer: Surveillance and Crime Prevention. Oxford University Press, Oxford.

Wheeler, S. M. (2013) Planning for Sustainability: Creating Livable, Equitable and Ecological Communities. Routledge, London; New York.

Williams, J. (2005) Designing Neighbourhoods for Social Interaction: The Case of Cohousing. Journal of Urban Design 10.2, 195-227.

Williams, K., Burton, E. and Jenks, M. (1996) Achieving the Compact city through Intensification: An Acceptable Option? In Jenks, M., E. Butron and K. Williams (eds.), The Compact City: A Sustainable Urban Form? E \& FN Spon, London; New York.

Winkler, T. and Duminy, J. (2016) Planning to change the world? Questioning the normative ethics of planning theories <sup/>. Planning Theory 15.2, 111-29.

Winston, N. (2014) Sustainable Communities? A Comparative Perspective on Urban Housing in the European Union. European Planning Studies 22.7, 1384-1406.

Winston, N. and Pareja Eastaway, M. (2008) Sustainable Housing in the Urban Context: International Sustainable Development Indicator Sets and Housing. Social Indicators Research 87.2, 211-21.

Yiftachel, O. and Hedgcock, D. (1993a) Urban social sustainability: The planning of an Australian city. Cities 10.2, 139-57.

Yiftachel, O. and Hedgcock, D. (1993b) Urban social sustainability: The planning of an Australian city. Cities 10.2, 139-57.

Yinger, J. (1995) Closed Doors, Opportunities Lost: Continuing Cost of Housing Discrimination. New edition edition. Russell Sage Foundation, New York.

Yoo, C. and Lee, S. (2016) Neighborhood Built Environments Affecting Social Capital and Social Sustainability in Seoul, Korea. Sustainability 8.12, 1346. 


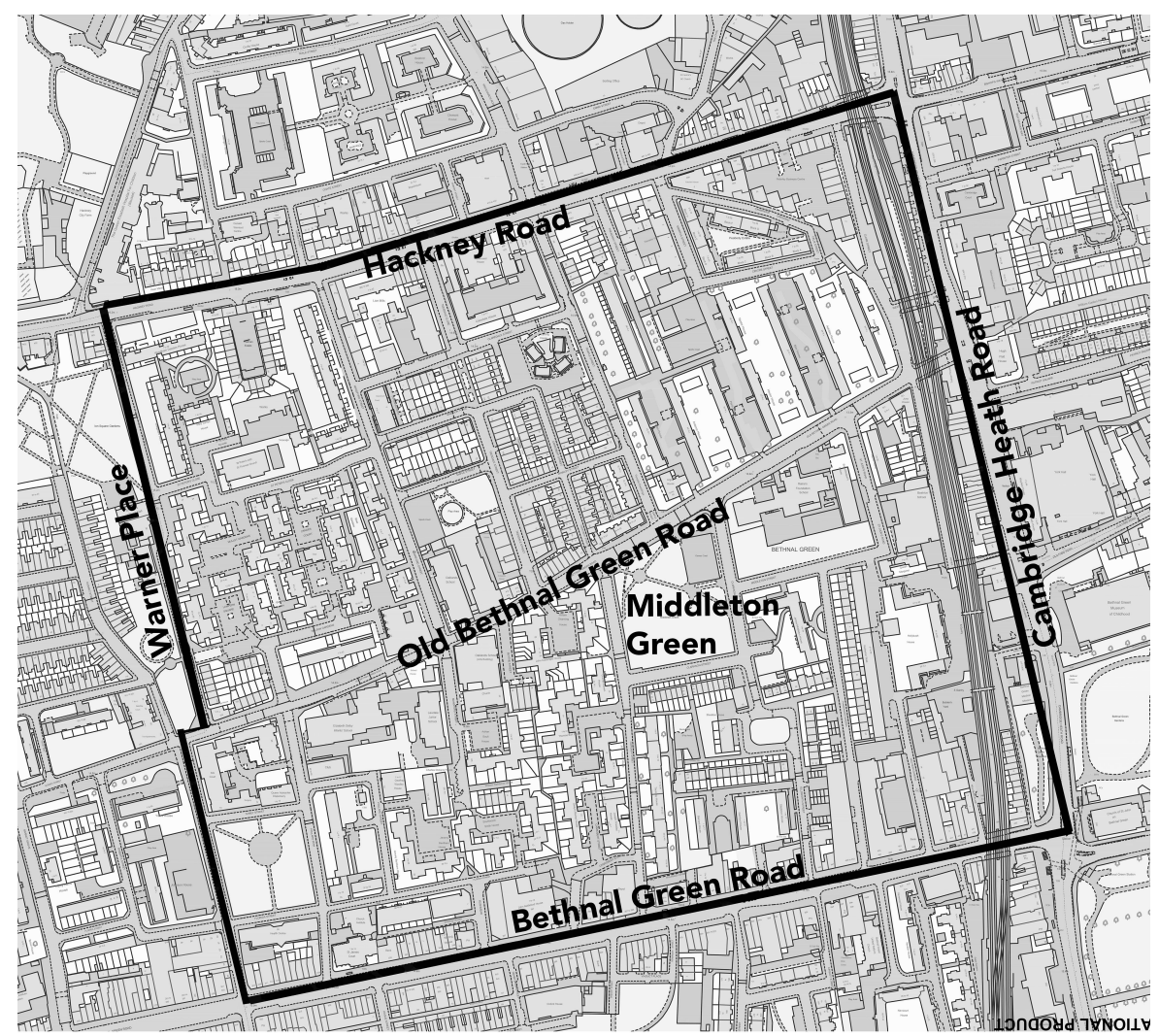

Fig. 1: Bethnal Green case study area
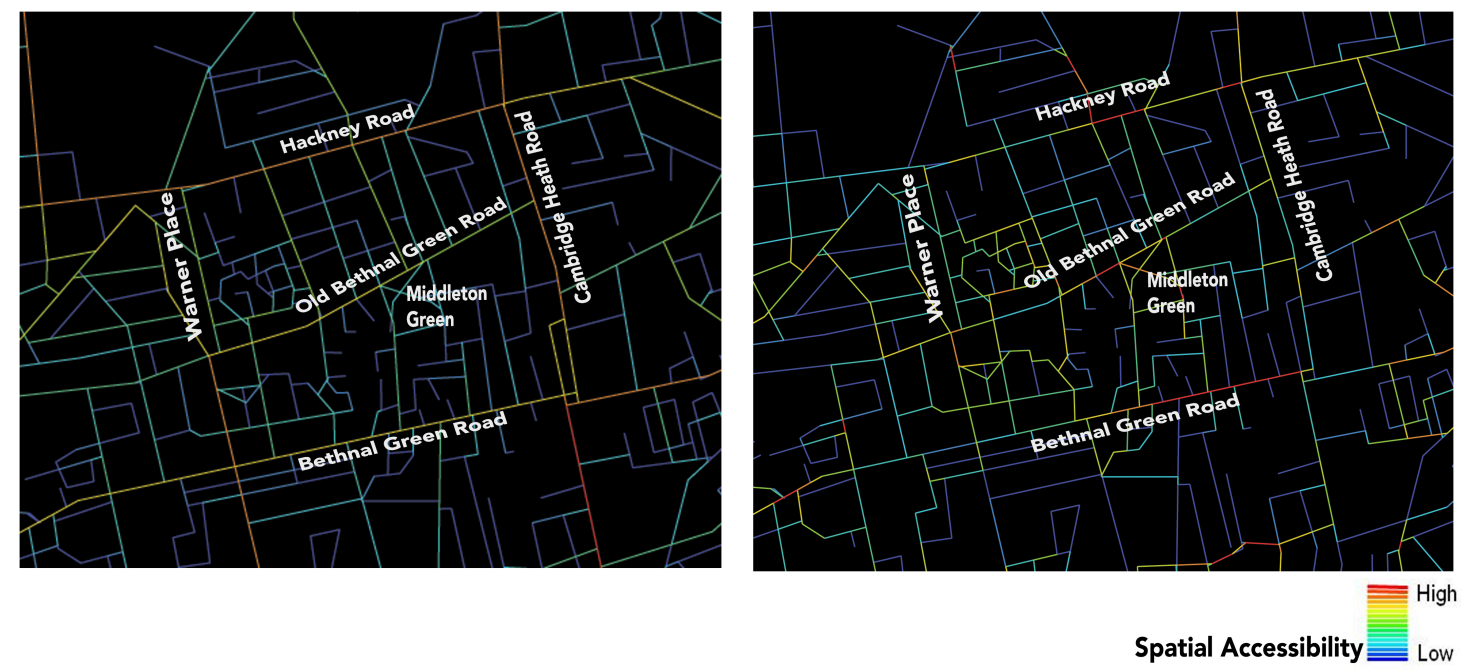

Fig. 2: Space Syntax Analysis of choice (movement flows). Left: Normalised choice (radius 10,000); Right: Normalised choice (radius 200) 
Table 1: Social Sustainability Pillars, Indicators, and Measures

\begin{tabular}{|c|c|c|c|c|}
\hline & Indicators & Brief Explanation & Measures & $\begin{array}{l}\text { Data Collection Sources } \\
\text { and Methods }\end{array}$ \\
\hline \multirow{5}{*}{ 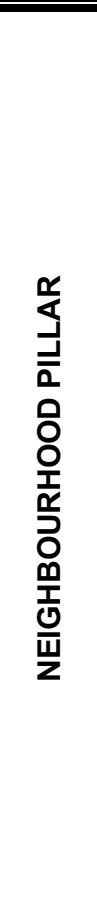 } & Density & $\begin{array}{l}\text { Concentration of individuals or physical } \\
\text { structures within a specific territorial } \\
\text { area }\end{array}$ & $\begin{array}{l}\text { Population density || Gross residential } \\
\text { density || Net residential density || FAR (Floor } \\
\text { Area Ration) || Coverage || Household } \\
\text { density }\end{array}$ & $\begin{array}{l}\text { National census || Local } \\
\text { plans || GIS maps || On- } \\
\text { site observation }\end{array}$ \\
\hline & Mixed Land Use & $\begin{array}{l}\text { Combination of different functions in a } \\
\text { determined place and their proximity } \\
\text { and diversity }\end{array}$ & $\begin{array}{l}\text { Gross residential/non-residential area ratio \| } \\
\text { Net residential/non-residential area ratio \| } \\
\text { Different land use types such as commercial, } \\
\text { green space, office, etc. (size and number) \| } \\
\text { Number of mixed use buildings/plots \| } \\
\text { Pattern of mixed use }\end{array}$ & $\begin{array}{l}\text { National census || Local } \\
\text { plans || GIS maps \| } \\
\text { Ordnance survey maps \| } \\
\text { On-site observation \| Site } \\
\text { survey }\end{array}$ \\
\hline & $\begin{array}{l}\text { Urban Pattern and } \\
\text { Connectivity }\end{array}$ & $\begin{array}{l}\text { Spatial arrangement and configuration } \\
\text { of different urban elements such as } \\
\text { streets, blocks, and buildings }\end{array}$ & $\begin{array}{l}\text { Block size (max, min, average, median) \| Lot } \\
\text { size (max, min, average, median) \| Number } \\
\text { of public transportation stops \| Length of } \\
\text { pedestrian paths \| Length of cycling paths } \| \\
\text { Integration and choice }\end{array}$ & $\begin{array}{l}\text { GIS maps || Ordnance } \\
\text { survey maps || On-site } \\
\text { observation }\end{array}$ \\
\hline & Building Typology & $\begin{array}{l}\text { Classification of buildings based on } \\
\text { common formal }\end{array}$ & $\begin{array}{l}\text { Floor area of houses || Built-up to plot area } \\
\text { ratio || House types percentage || Building } \\
\text { height percentage }\end{array}$ & $\begin{array}{l}\text { GIS maps || Ordnance } \\
\text { survey maps || On-site } \\
\text { observation || Site survey }\end{array}$ \\
\hline & Quality of Centre & $\begin{array}{l}\text { Spatial quality of the neighbourhood's } \\
\text { focal point. }\end{array}$ & $\begin{array}{l}\text { Open space size || Connectivity || Land use } \\
\text { pattern || Urban furniture }\end{array}$ & $\begin{array}{l}\text { GIS maps || Ordnance } \\
\text { survey maps || On-site } \\
\text { observation || Site survey }\end{array}$ \\
\hline \multirow{2}{*}{ 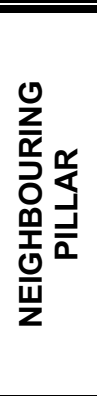 } & Access to facilities & $\begin{array}{l}\text { Availability of key urban amenities and } \\
\text { equal accessibility of these amenities } \\
\text { to all the members of the community }\end{array}$ & $\begin{array}{l}\text { Availability of daily use shopping \| Means of } \\
\text { accessing workplace \| Means of access to } \\
\text { different urban facilities such as small shops, } \\
\text { supermarket, chemist, post office, etc. }\end{array}$ & \multirow[t]{2}{*}{$\begin{array}{l}\text { Household survey } \\
\text { (questionnaire) }\end{array}$} \\
\hline & $\begin{array}{l}\text { Social networking } \\
\text { and interaction }\end{array}$ & $\begin{array}{l}\text { Interaction between individuals and } \\
\text { non-verbal/verbal interrelationships } \\
\text { between them }\end{array}$ & $\begin{array}{l}\text { Number of neighbours known by name \| } \\
\text { Frequency of meeting neighbours \| Number } \\
\text { of friends in the neighbourhood \| Number of } \\
\text { neighbours frequently visited || Asking help } \\
\text { from neighbours || Exchange of help and } \\
\text { support with neighbours }\end{array}$ & \\
\hline
\end{tabular}




\begin{tabular}{|c|c|c|c|c|}
\hline & Safety and security & $\begin{array}{l}\text { External and internal threats and } \\
\text { feeling of being safe at the urban } \\
\text { space for all inhabitants }\end{array}$ & $\begin{array}{l}\text { Feeling of safety in daytime \| Feeling of } \\
\text { safety after dark || Safety of open spaces \| } \\
\text { Children safety on the streets \| Safety of } \\
\text { pavements and sidewalks } \| \text { Being victim of } \\
\text { crime \|| Presence of police at the } \\
\text { neighbourhood }\end{array}$ & \\
\hline & $\begin{array}{l}\text { Sense of } \\
\text { attachment }\end{array}$ & $\begin{array}{l}\text { Identification with the place and feeling } \\
\text { attached to it }\end{array}$ & $\begin{array}{l}\text { Feeling of neighbourhood attachment \| } \\
\text { Neighbourhood proud || Feeling of being at } \\
\text { home in the neighbourhood || Missing } \\
\text { neighbourhood while away \|| Desirability of } \\
\text { neighbourhood || Desire to leave the } \\
\text { neighbourhood }\end{array}$ & \\
\hline & Participation & $\begin{array}{l}\text { Active involvement in neighbourhood- } \\
\text { related initiatives and dealing with } \\
\text { neighbourhood problems }\end{array}$ & $\begin{array}{l}\text { Knowing community-based organisations \|| } \\
\text { Membership in community organisations \| } \\
\text { Participation in religious activities \| Being } \\
\text { involved by local authorities } \| \text { Response to } \\
\text { the involvement requests made by local } \\
\text { authorities } \| \text { Knowing neighbourhood } \\
\text { problems }\end{array}$ & \\
\hline & $\begin{array}{l}\text { Neighbourhood } \\
\text { quality perception }\end{array}$ & $\begin{array}{l}\text { Satisfaction of residents with their } \\
\text { immediate environment and } \\
\text { neighbourhood quality }\end{array}$ & $\begin{array}{l}\text { Perception of building crowding \| } \\
\text { Perception of population crowding } \| \\
\text { Satisfaction with noise } \\
\text { pollution/neighbours/cleanliness of } \\
\text { neighbourhood/street lighting/maintenance } \\
\text { of public spaces/ neighbourhood } \\
\text { reputation/traffic congestion }\end{array}$ & \\
\hline & $\begin{array}{l}\text { Home quality } \\
\text { perception }\end{array}$ & $\begin{array}{l}\text { The degree of congruence between the } \\
\text { actual and the desirable home } \\
\text { conditions and residents' perception of } \\
\text { different aspects of home }\end{array}$ & $\begin{array}{l}\text { Satisfaction with home in terms of } \\
\text { privacy/noise/room size/room number/ } \\
\text { parking || Desire to move out || Reason for } \\
\text { moving }\end{array}$ & \\
\hline 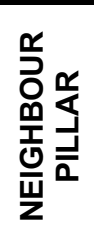 & Social Mix & $\begin{array}{l}\text { Population profile of the neighbourhood } \\
\text { inhabitants and socio-economic } \\
\text { diversity }\end{array}$ & $\begin{array}{l}\text { Age/Gender distribution \|| Ethnicity mix \| } \\
\text { Length of residency \| Household size \| } \\
\text { Household type \| Household ownership \| } \\
\text { Household income \|| Employment status \| } \\
\text { Accommodation type and characteristics \| } \\
\text { Education status }\end{array}$ & $\begin{array}{l}\text { National census || Local } \\
\text { authorities || GIS maps \| } \\
\text { Household survey }\end{array}$ \\
\hline
\end{tabular}


Table 2: 'neighbour' profile of the participant households.

\begin{tabular}{|c|c|c|c|c|c|c|c|c|c|c|c|c|c|c|c|c|c|c|}
\hline \multicolumn{2}{|c|}{$\begin{array}{l}\text { Place of } \\
\text { born (\%) }\end{array}$} & \multicolumn{3}{|c|}{ Ethnicity (\%) } & \multicolumn{6}{|c|}{ Household size (\%) } & \multicolumn{5}{|c|}{$\begin{array}{c}\text { Household } \\
\text { composition (\%) }\end{array}$} & \multicolumn{3}{|c|}{ Household Tenure (\%) } \\
\hline 光 & $\begin{array}{l}\frac{2}{3} \\
\frac{0}{0} \\
\frac{0}{0}\end{array}$ & 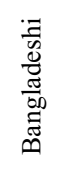 & 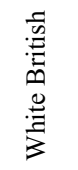 & 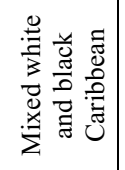 & 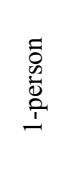 & 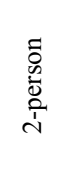 & 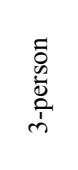 & 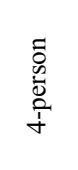 & 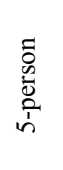 & 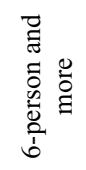 & 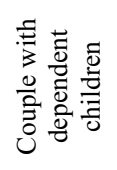 & 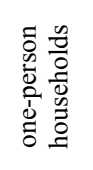 & 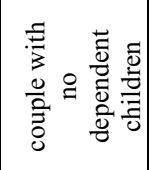 & 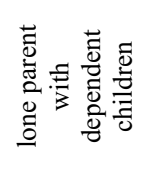 & 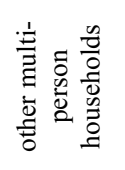 & 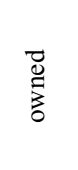 & 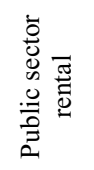 & 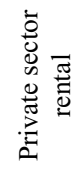 \\
\hline 63 & 37 & 36.7 & 29.6 & 16.3 & 13.1 & 19.2 & 17.2 & 16.2 & 10.1 & 23.2 & 35.8 & 14.7 & 12.6 & 6.3 & 30.6 & 32.1 & 47.4 & 26.3 \\
\hline
\end{tabular}


Table 3: Overall accessibility of urban services

\begin{tabular}{|c|c|c|c|c|}
\hline & Walking & Biking & Public transport & Private car \\
\hline $\begin{array}{c}\text { Accessibility of } \\
\text { urban services }\end{array}$ & 82.6 & 3.1 & 7.8 & 6.3 \\
\hline
\end{tabular}


Table 4: Feeling of safety in neighbourhood

\begin{tabular}{|c|c|c|c|c|c|}
\hline Safety in neighbourhood & 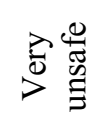 & 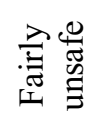 & 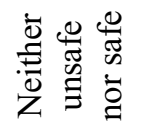 & 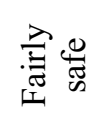 & $\vec{D}_{\overrightarrow{0}}^{\overrightarrow{0}}$ \\
\hline safety feeling walking daytime & 1.0 & 6.1 & 6.1 & 35.7 & 51.0 \\
\hline safety feeling walking in dark & 9.5 & 20.0 & 13.7 & 40.0 & 16.8 \\
\hline safety of parks & 7.6 & 17.6 & 18.5 & 45.7 & 10.9 \\
\hline traffic safety of children on the streets around home & 8.5 & 25.5 & 21.3 & 40.4 & 4.1 \\
\hline safety of pavements and sidewalks & 2.1 & 13.5 & 15.6 & 58.3 & 10.4 \\
\hline overall feeling of safety & 1.0 & 16.3 & 18.4 & 49.0 & 15.3 \\
\hline
\end{tabular}


Table 5: Sense of attachment

\begin{tabular}{|l|l|l|l|l|l|}
\hline & $\begin{array}{l}\text { Strongly } \\
\text { disagree }\end{array}$ & Disagree & $\begin{array}{l}\text { Neither } \\
\text { agree not } \\
\text { disagree }\end{array}$ & Agree & $\begin{array}{l}\text { Strongly } \\
\text { agree }\end{array}$ \\
\hline Proud of neighbourhood & 2.1 & 14.4 & 38.1 & 37.1 & 8.2 \\
\hline Feel at home in neighbourhood & 1.0 & 4.1 & 15.5 & 57.7 & 21.6 \\
\hline Neighbourhood to live in & 8.3 & 13.5 & 29.2 & 32.3 & 16.7 \\
\hline Missing neighbourhood & 6.2 & 14.4 & 25.8 & 39.2 & 14.4 \\
\hline
\end{tabular}


Table 6: Satisfaction with neighbourhood

\begin{tabular}{|l|l|l|l|l|l|}
\hline & $\begin{array}{l}\text { Very } \\
\text { dissatisfied }\end{array}$ & Dissatisfied & $\begin{array}{l}\text { Neither } \\
\text { dissatisfied } \\
\text { not satisfied }\end{array}$ & Satisfied & $\begin{array}{l}\text { Very } \\
\text { satisfied }\end{array}$ \\
\hline Satisfaction with noise & 10.5 & 29.5 & 24.2 & 32.6 & 3.2 \\
\hline Satisfaction with neighbours & 0.0 & 7.3 & 30.2 & 52.1 & 10.4 \\
\hline Satisfaction with cleanliness & 13.8 & 28.7 & 22.3 & 34.0 & 1.1 \\
\hline Satisfaction with lighting & 9.4 & 18.8 & 13.5 & 49.0 & 9.4 \\
\hline Satisfaction with maintenance & 10.6 & 16.0 & 30.9 & 39.4 & 3.2 \\
\hline $\begin{array}{l}\text { Satisfaction with neighbourhood } \\
\text { reputation }\end{array}$ & 4.2 & 18.8 & 43.8 & 30.2 & 3.1 \\
\hline $\begin{array}{l}\text { Satisfaction with traffic } \\
\text { congestion }\end{array}$ & 12.5 & 37.5 & 32.3 & 15.6 & 2.1 \\
\hline Satisfaction with green space & 7.4 & 10.6 & 19.1 & 52.1 & 10.6 \\
\hline $\begin{array}{l}\text { Overall neighbourhood } \\
\text { satisfaction }\end{array}$ & 0.0 & 12.6 & 20.0 & 55.8 & 11.6 \\
\hline
\end{tabular}


Table 7: Satisfaction with home

\begin{tabular}{|l|l|l|l|l|l|}
\hline & $\begin{array}{l}\text { Very } \\
\text { dissatisfied }\end{array}$ & Dissatisfied & $\begin{array}{l}\text { Neither } \\
\text { dissatisfied } \\
\text { not satisfied }\end{array}$ & Satisfied & $\begin{array}{l}\text { Very } \\
\text { satisfied }\end{array}$ \\
\hline Satisfaction with privacy & 1.1 & 9.8 & 15.2 & 59.8 & 14.1 \\
\hline Satisfaction with noise & 4.3 & 25.8 & 18.3 & 43.0 & 8.6 \\
\hline Satisfaction with size of rooms & 5.3 & 8.4 & 21.1 & 54.7 & 10.5 \\
\hline $\begin{array}{l}\text { Satisfaction with number of } \\
\text { rooms }\end{array}$ & 4.3 & 12.9 & 19.4 & 52.7 & 10.8 \\
\hline Satisfaction with parking space & 14.0 & 18.3 & 30.1 & 30.1 & 7.5 \\
\hline Overall home satisfaction & 2.1 & 7.4 & 13.8 & 59.6 & 17.0 \\
\hline
\end{tabular}


Table 8: Weight of indicators by participants

\begin{tabular}{|l|l|l|l|l|l|l|l|}
\hline Indicators & $\begin{array}{l}\text { Access } \\
\text { to } \\
\text { facilities }\end{array}$ & $\begin{array}{l}\text { Interaction } \\
\text { and } \\
\text { Networking }\end{array}$ & $\begin{array}{l}\text { Safety } \\
\text { and } \\
\text { Security }\end{array}$ & $\begin{array}{l}\text { Sense of } \\
\text { Attachment }\end{array}$ & $\begin{array}{l}\text { Participation in } \\
\text { Neighbourhood }\end{array}$ & $\begin{array}{l}\text { Quality of } \\
\text { Neighbourhood } \\
\text { Perception }\end{array}$ & $\begin{array}{l}\text { Quality of } \\
\text { Home } \\
\text { Perception }\end{array}$ \\
\hline Rate & 4.09 & 3.34 & 4.18 & 3.66 & 2.81 & 4.05 & 4.29 \\
\hline $\begin{array}{l}\text { Rank } \\
\text { (highest }= \\
\text { 1) }\end{array}$ & 3 & 6 & 2 & 5 & 7 & 4 & 1 \\
\hline
\end{tabular}


Table 9: Value of indicators

\begin{tabular}{|l|l|l|l|l|l|l|l|}
\hline Indicators & $\begin{array}{l}\text { Access } \\
\text { to } \\
\text { facilities }\end{array}$ & $\begin{array}{l}\text { Interaction } \\
\text { and } \\
\text { Networking }\end{array}$ & $\begin{array}{l}\text { Safety } \\
\text { and } \\
\text { Security }\end{array}$ & $\begin{array}{l}\text { Sense of } \\
\text { Attachment }\end{array}$ & $\begin{array}{l}\text { Participation in } \\
\text { Neighbourhood }\end{array}$ & $\begin{array}{l}\text { Quality of } \\
\text { Neighbourhood } \\
\text { Perception }\end{array}$ & $\begin{array}{l}\text { Quality } \\
\text { of Home } \\
\text { Percepti } \\
\text { on }\end{array}$ \\
\hline Value & 178.75 & 98.60 & 132.77 & 128.25 & 69.13 & 105.10 & 126.30 \\
\hline $\begin{array}{l}\text { Rank } \\
\text { (highest }= \\
1)\end{array}$ & 1 & 6 & 2 & 3 & 7 & 5 & 4 \\
\hline
\end{tabular}


Table 10: SSEI-Neighbourhood

\begin{tabular}{|c|c|c|c|}
\hline & \multirow[t]{2}{*}{ Relevant Key Research Findings } & \multicolumn{2}{|c|}{ Recommendations } \\
\hline & & Policy and Planning & Design \\
\hline 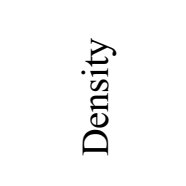 & $\begin{array}{l}\text { Population density (190.8 pph) higher } \\
\text { than Bethnal Green North Ward ( } 166.3 \\
\text { pph). }\end{array}$ & $\begin{array}{l}\text { Sustaining status-quo population and } \\
\text { building density. }\end{array}$ & $\begin{array}{l}\text { No major new development } \\
\text { Refurbishment of empty buildings for } \\
\text { different land use, such as residential, } \\
\text { office, etc. }\end{array}$ \\
\hline 总总 & $\begin{array}{l}17 \% \text { of plots mixed use, concentrated } \\
\text { along peripheral streets. } \\
\text { A mixed use area at the centre around } \\
\text { Winkley Street. } \\
\text { Various urban amenities across the } \\
\text { neighbourhood. } \\
\text { Mid to high-rise residential blocks at the } \\
\text { centre with plenty of open space between } \\
\text { them. }\end{array}$ & $\begin{array}{l}\text { Facilitating planning permissions for the } \\
\text { old properties and workshops around } \\
\text { Winkley Street. } \\
\text { Facilitating planning permissions for non- } \\
\text { residential use across the neighbourhood. }\end{array}$ & $\begin{array}{l}\text { Standard retrofitting and refurbishment of } \\
\text { properties around Winkley Street. }\end{array}$ \\
\hline 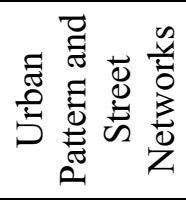 & $\begin{array}{l}\text { Integrated street pattern. } \\
\text { Multiple means of transportation available } \\
\text { on the neighbourhoods borders. } \\
\text { No cycling path across the streets. }\end{array}$ & $\begin{array}{l}\text { Studying the capacity of Old Bethnal } \\
\text { Green Road for setting an interior bus line } \\
\text { in future transportation plans. }\end{array}$ & $\begin{array}{l}\text { Re-considering pedestrian paths and } \\
\text { physical man-made barriers for achieving } \\
\text { greater spatial integrity. }\end{array}$ \\
\hline 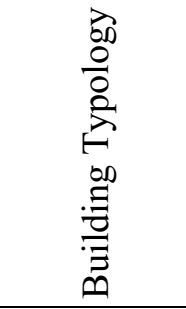 & $\begin{array}{l}\text { A mass of post-war residential } \\
\text { development. } \\
\text { Old Bethnal Green Road Conservation } \\
\text { Area at the centre. } \\
88 \% \text { of buildings flat. } \\
34 \% \text { of buildings } 3 \text {-storey, } 20 \% \text { 2-storey, } \\
18 \% \text {-storey. }\end{array}$ & $\begin{array}{l}\text { Safeguarding diversity of building } \\
\text { typology and giving priority to } \\
\text { preservation of small number of Victorian } \\
\text { houses and other terraced houses. }\end{array}$ & $\begin{array}{l}\text { Careful implementation of } \\
\text { recommendations provided in Hackney } \\
\text { Road Conservation Area, and Old Bethnal } \\
\text { Green Road Conservation Area documents. }\end{array}$ \\
\hline 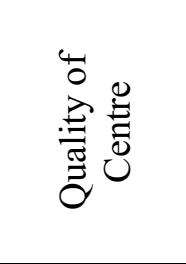 & $\begin{array}{l}\text { The intersection of the Old Bethnal Green } \\
\text { Road and Canrobert Street, with adjacent } \\
\text { Middleton Park, a potential centre. } \\
\text { A small variety of local shops available. } \\
\text { Empty workshops with capacity of } \\
\text { refurbishment. }\end{array}$ & $\begin{array}{l}\text { Including a development scheme for } \\
\text { upgrading Middleton Park and Winkley } \\
\text { Estate area to serve as neighbourhood } \\
\text { centre. }\end{array}$ & $\begin{array}{l}\text { Improving the quality of Middleton Park in } \\
\text { terms of urban facilities, playground, and } \\
\text { maintenance } \\
\text { Improving environmental quality of } \\
\text { Winkley Estate and re-considering traffic } \\
\text { regulations. }\end{array}$ \\
\hline
\end{tabular}



Table 11: SSEI-Neighbouring

\begin{tabular}{|c|c|c|c|}
\hline & \multirow{2}{*}{$\begin{array}{l}\text { Relevant Key Research Findings } \\
\text { (\% is related to participants in the questionnaire) }\end{array}$} & \multicolumn{2}{|c|}{ Recommendations } \\
\hline & & Policy and Planning & Design \\
\hline 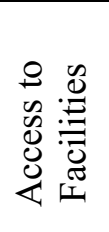 & $\begin{array}{l}\text { Walking as the dominant mode for achieving urban } \\
\text { facilities. } \\
82.6 \% \text { of the participants walk to reach basic urban } \\
\text { services. } \\
\text { Cycling as the least used mean of transportation. }\end{array}$ & $\begin{array}{l}\text { Introducing mixed land use as a main } \\
\text { urban policy for future local plans to } \\
\text { accommodate more urban services within } \\
\text { neighbourhood space. }\end{array}$ & $\begin{array}{l}\text { Dedicated cycle paths across the } \\
\text { neighbourhood. } \\
\text { Implementing traffic calming measures } \\
\text { for higher safety for cyclists. }\end{array}$ \\
\hline 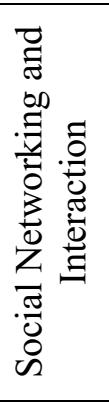 & $\begin{array}{l}\text { Neighbours known by name higher than UK average. } \\
\text { Participants have } 7.34 \text { friends in the neighbourhood. } \\
21 \% \text { have no friend. } \\
42.4 \% \text { never visit their neighbours at home or other } \\
\text { places. }\end{array}$ & $\begin{array}{l}\text { Encouraging social diversity and multi- } \\
\text { ethnicity. } \\
\text { Encouraging and funding communal } \\
\text { activities such as feasts, communal } \\
\text { gardening, etc. as well as neighbourhood- } \\
\text { bases communities. } \\
\text { Encouraging mixed land use policy which } \\
\text { provides possibility for spaces of } \\
\text { socialising such as cafes and restaurants. }\end{array}$ & $\begin{array}{l}\text { Improving physical quality of communal } \\
\text { areas such as parks, open spaces, etc. to } \\
\text { provide more space for socialising. }\end{array}$ \\
\hline 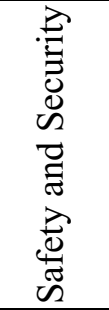 & $\begin{array}{l}\text { Only } 4.3 \% \text { believe children are very safe on the streets. } \\
34 \% \text { believe children are not safe on the streets from } \\
\text { traffic } \\
17.6 \% \text { feel fairly unsafe in parks } \\
42.4 \% \text { rate presence of police at the neighbourhood as } \\
\text { fairly weak. }\end{array}$ & $\begin{array}{l}\text { A comprehensive traffic calming plan for } \\
\text { the entire neighbourhood. } \\
\text { More efficient police presence. } \\
\text { A comprehensive natural surveillance } \\
\text { strategy for the neighbourhood. }\end{array}$ & $\begin{array}{l}\text { Implementing safety measures for } \\
\text { pedestrians } \\
\text { More lightening in public areas and } \\
\text { parks during dark time. }\end{array}$ \\
\hline 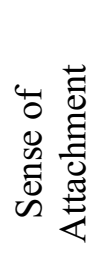 & $\begin{array}{l}\text { The average neighbourhood residency length is } 19.11 \\
\text { years. } \\
69.8 \% \text { have no plan to move out of the neighbourhood. } \\
\text { Reasons for not moving: good quality of } \\
\text { neighbourhood }(26.8 \%) \text {, satisfaction with neighbours } \\
(26.8 \%) \text {, job reasons }(17.1 \%) \text {. }\end{array}$ & $\begin{array}{l}\text { Protecting tenancy agreements and } \\
\text { contracts for enabling long-term residency } \\
\text { in public and private houses. }\end{array}$ & $\begin{array}{l}\text { Enhancing quality of neighbourhood and } \\
\text { its attractiveness. }\end{array}$ \\
\hline
\end{tabular}




\begin{tabular}{|c|c|c|c|}
\hline 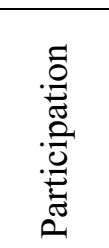 & $\begin{array}{l}77.1 \% \text { not member of any community-based } \\
\text { organisation. } \\
22.7 \% \text { actively participating in community centre } \\
\text { activities. } \\
72.3 \% \text { rate their level of involvement very low or low. }\end{array}$ & $\begin{array}{l}\text { Supporting community-led and } \\
\text { neighbourhood-based organisations. } \\
\text { Frequent reference to inhabitants by local } \\
\text { authorities and engaging them with } \\
\text { decision making processes. }\end{array}$ & \\
\hline 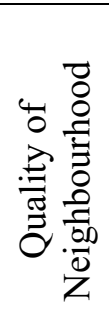 & $\begin{array}{l}\text { A moderate satisfaction with neighbours, street } \\
\text { lighting, maintenance, neighbourhood reputation, and } \\
\text { green space. } \\
\text { Complains about noise and cleanliness of } \\
\text { neighbourhood space. } \\
50 \% \text { highly or relatively dissatisfied with traffic } \\
\text { congestion }\end{array}$ & $\begin{array}{l}\text { More efficient neighbourhood } \\
\text { maintenance, particularly in public spaces } \\
\text { and waste management. }\end{array}$ & $\begin{array}{l}\text { Implementing traffic calming measures. } \\
\text { More litter bins in public spaces. }\end{array}$ \\
\hline 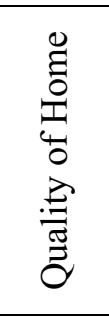 & $\begin{array}{l}\text { Moderate satisfaction with privacy, size of rooms, and } \\
\text { number of rooms. } \\
\text { Moderate dissatisfaction with noise and parking spaces } \\
\text { around the home. } \\
77 \% \text { satisfied or very satisfied with their home. } \\
70.3 \% \text { have no plan to change their home. } \\
\text { Average home residency length } 13.4 \text { years. }\end{array}$ & $\begin{array}{l}\text { Incentives for home improvement and } \\
\text { refurbishment plans. }\end{array}$ & $\begin{array}{l}\text { Improvement and standardisation of } \\
\text { home quality. }\end{array}$ \\
\hline
\end{tabular}

